\title{
Microstructures and Tensile Fracture Behavior of 2219 Wrought Al-Cu Alloys with Different Impurity of Fe
}

\author{
Daofen $\mathrm{Xu}{ }^{1,2,3}$, Changjun Zhu ${ }^{4, *}$, Chengfu $\mathrm{Xu}{ }^{2}$ and Kanghua Chen ${ }^{1,3,4}$ \\ 1 National Key Laboratory of Science and Technology for National Defence on High-Strength Structural \\ Materials, Central South University, Changsha 410083, China; xu_daofen@126.com (D.X.); \\ khchen@csu.edu.cn (K.C.) \\ 2 Department of Mechanical Engineering, Guilin University of Aerospace Technology, Guilin 541004, China; \\ Xucf@guat.edu.cn \\ 3 Light Alloy Research Institute, Central South University, Changsha 410083, China \\ 4 State Key Laboratory of Powder Metallurgy, Central South University, Changsha 410083, China \\ * Correspondence: zhucj96@csu.edu.cn
}

check for updates

Citation: Xu, D.; Zhu, C.; Xu, C.; Chen, K. Microstructures and Tensile Fracture Behavior of 2219 Wrought Al-Cu Alloys with Different Impurity of Fe. Metals 2021, 11, 174. https:// doi.org/10.3390/met11010174

Received: 28 December 2020

Accepted: 15 January 2021

Published: 19 January 2021

Publisher's Note: MDPI stays neutral with regard to jurisdictional claims in published maps and institutional affiliations.

Copyright: (c) 2021 by the authors. Licensee MDPI, Basel, Switzerland. This article is an open access article distributed under the terms and conditions of the Creative Commons Attribution (CC BY) license (https:// creativecommons.org/licenses/by/ $4.0 /)$.

\begin{abstract}
The Fe-rich intermetallic phases have a broadly detrimental effect on the mechanical properties of $\mathrm{Al}-\mathrm{Cu}$ alloy. In this paper, the continuous evolution of Fe-rich intermetallics and their effects on mechanical properties, especially the tensile fracture behavior of 2219 wrought $\mathrm{Al}-\mathrm{Cu}$ alloys as a function of Fe content against different processing approaches (i.e., as-cast, homogenization, multidirectional forging, and solution-peak aging treatment) were investigated using optical microscopy, scanning electron microscopy, and tensile tests. The results indicated that needle-like $\mathrm{Al}_{7} \mathrm{Cu}_{2} \mathrm{Fe}$ or $\mathrm{Al}_{7} \mathrm{Cu}_{2}(\mathrm{Fe}, \mathrm{Mn})$ intermetallics mainly presented in the final microstructures of all alloys with various $\mathrm{Fe}$ contents. The size and number of $\mathrm{Al}_{7} \mathrm{Cu}_{2} \mathrm{Fe} / \mathrm{Al}_{7} \mathrm{Cu}_{2}(\mathrm{Fe}, \mathrm{Mn})$ intermetallics increased with the increase of Fe content. The increase of Fe content had little influence on the ultimate tensile strength and yield strength, while obvious deterioration in the elongation, because fracture initiators mainly occurred at the $\mathrm{Al}_{7} \mathrm{Cu}_{2} \mathrm{Fe} / \mathrm{Al}_{7} \mathrm{Cu}_{2}(\mathrm{Fe}, \mathrm{Mn})$ particles or particles-matrix interface. Therefore, the $2219 \mathrm{Al}-\mathrm{Cu}$ alloy with $0.2 \mathrm{wt}$.\% Fe content presented relatively low tensile ductility. The tensile fracture mechanism has been discussed in detail.
\end{abstract}

Keywords: 2219 wrought $\mathrm{Al}-\mathrm{Cu}$ alloys; $\mathrm{Fe}$ content; $\mathrm{Al}_{7} \mathrm{Cu}_{2} \mathrm{Fe} / \mathrm{Al}_{7} \mathrm{Cu}_{2}(\mathrm{Fe}, \mathrm{Mn})$; tensile fracture behavior

\section{Introduction}

The heat-treatable type 2xxx Al-Cu alloys have been widely used in transportation and aerospace industry owing to its high specific strength and good weldability. Such as the employment of $2219 \mathrm{Al}-\mathrm{Cu}$ alloy in fabricating propellant tank of large launch vehicle [1,2] and the utilization of $2519 \mathrm{Al}-\mathrm{Cu}$ alloy as structure component of armored vehicle [3]. It is well known that the solubility of impurity $\mathrm{Fe}$ in $\mathrm{Al}-\mathrm{Cu}$ alloys is very poor. As a result, Fe-rich intermetallics, including needle-like morphology $\mathrm{Al}_{7} \mathrm{Cu}_{2} \mathrm{Fe} / \mathrm{Al}_{7} \mathrm{Cu}_{2}(\mathrm{Fe}$, $\mathrm{Mn})$ (named as $\beta-\mathrm{Fe})[4]$ and $\mathrm{Al}_{3}(\mathrm{FeMn})[5]$ or Chinese script-shaped $\mathrm{Al}_{15}(\mathrm{FeMn})_{3}(\mathrm{CuSi})_{2}$ (named as $\alpha-\mathrm{Fe}$ ) [6], $\mathrm{Al}_{6}\left(\mathrm{FeMn}\right.$ ) [7], and $\mathrm{Al}_{\mathrm{m}} \mathrm{Fe}$ [8] phases, can be formed readily during the solidification process. Generally, these Fe-rich intermetallics are hard to dissolve into the $\alpha-\mathrm{Al}$ matrix during solution treatment and can act as crack initiation sites due to its incompatible plastic deformation with the softer $\alpha$ - $\mathrm{Al}$ matrix during deformation, thereby deteriorating the mechanical properties and in particular, the fracture properties of the alloy $[2,8]$. Therefore, a low upper limit of Fe content can be set in wrought aluminum alloy. For instance, Fe content is usually limited to a maximum amount of $0.3 \mathrm{wt} . \%$ in 2219 wrought $\mathrm{Al}-\mathrm{Cu}$ alloy.

The needle-like $\beta$-Fe particles have been thought of as the most detrimental Fe-rich intermetallics. Thus, it is necessary to modify, refine, and even inhibit the formation of the needle-like Fe-rich intermetallics. Several effective methods have been employed to 
prevent the form of needle-like $\beta$-Fe particles or transform the needle-like morphology into Chinese script-shaped Fe-rich intermetallics, which is thought to be less harmful to the mechanical properties of the alloy. These methods include adding Mn and/or Si as neutralization elements, increasing cooling rate during solidification and the improvement in melt quality (i.e., squeeze or ultrasonic casting and superheated melt).

In the work of Tseng et al. [7,9], the needle-like $\beta$-Fe phase was reported to be the dominant Fe-rich intermetallics in A206 alloy when Fe content was lower than $0.3 \mathrm{wt} . \%$, while the $\beta$-Fe phase was found to partly transform into Chinese script-shaped Fe-rich intermetallics when Mn content was more than $0.29 \mathrm{wt} . \%$. With further addition of $\mathrm{Mn}$ to $0.66 \mathrm{wt} . \%$, the $\beta-\mathrm{Fe}$ phase completely converted into Chinese script-shaped Fe-rich intermetallics. Liu et al. [10] found that the combined addition of both $\mathrm{Mn}$ and $\mathrm{Si}$ was more helpful to transform $\beta$-Fe into $\alpha$-Fe than the individual addition of either $\mathrm{Mn}$ or Si. Based on the data from $206 \mathrm{Al}-\mathrm{Cu}$ alloys with different $\mathrm{Fe}, \mathrm{Mn}$, and $\mathrm{Si}$ contents [11-13], it seems that the lower Fe content, the higher $\mathrm{Mn} / \mathrm{Fe}$, and/or $\mathrm{Si} / \mathrm{Fe}$ ratios for the efficient modification of $\beta$-Fe phase into Chinese script-shaped Fe-rich intermetallics. For instance, both $\mathrm{Mn} / \mathrm{Fe}$ and $\mathrm{Si} / \mathrm{Fe}$ ratios are about 1 in $206 \mathrm{Al}-\mathrm{Cu}$ alloys with $0.3 \mathrm{wt} . \% \mathrm{Fe}$ [6], but about 2 at $0.15 \mathrm{wt} . \% \mathrm{Fe}[10,12,13]$, even up to 13 (Mn/Fe ratio) at $0.05 \mathrm{wt} . \% \mathrm{Fe}-0.01 \mathrm{wt} . \%$ Si [7].

Increasing the solidified cooling rate is another widely used way to refine Fe-rich intermetallic particles. For instance, research on the $\mathrm{Al}-\mathrm{Mg}$ (Mg 4.7, $\mathrm{Mn} \mathrm{0.76,} \mathrm{Cr} 0.14$, Fe 0.22, Si 0.15, Cu 0.014, wt.\%) and Al-Cu (Cu 4.97, Fe 0.4, Si 0.12, Zn 0.11, Ni 0.08, wt.\%) alloys indicated that almost all the alloying elements are dissolved into the $\alpha$-Al matrix due to a sufficiently high cooling rate of $10^{5} \sim 10^{7} \mathrm{~K} / \mathrm{s}$ during melt spinning $[14,15]$. Chobaut et al. [16] also found that the coarse Fe-rich intermetallics in AA2618 Al-Cu$\mathrm{Mg}$ alloy could be completely inhibited under the condition of near-rapid cooling rate. However, Liu et al. [10] studied the influence of cooling rate on the formation of Ferich intermetallics in $\mathrm{Al}-\mathrm{Cu}$ alloys and found that there existed a critical cooling rate to completely hinder the formation of $\beta$-Fe at a given alloy composition. Normally, a higher cooling rate was required at the lower contents of $\mathrm{Mn}$ and $\mathrm{Si}$. In other words, $\beta-\mathrm{Fe}$ intermetallics compound cannot be completely eliminated in the $\mathrm{Al}-\mathrm{Cu}$ alloys with low levels of $\mathrm{Mn}$ and $\mathrm{Si}$. This phenomena was also observed in the $\mathrm{Al}-5 \mathrm{Mg}-0.8 \mathrm{Mn}-\mathrm{xFe}$ alloys with low content of $\mathrm{Si}$ in which the morphology of $\mathrm{Al}_{6}(\mathrm{CuFe})$ phase did not change under a near-rapid cooling rate of $20^{\circ} \mathrm{C} / \mathrm{s}$ [13].

In addition, in the study of Zhang and Lin et al. [5,12], the needle-like $\beta$-Fe completely disappeared in the $\mathrm{Al}-5.0 \mathrm{Cu}-0.6 \mathrm{Mn}-0.5 \mathrm{Fe}$ squeeze cast alloy with an applied pressure of $75 \mathrm{MPa}$. However, the metastable Chinese script-shaped $\alpha-\mathrm{Fe}, \mathrm{Al}_{6}(\mathrm{FeMn}), \mathrm{Al}_{\mathrm{m}} \mathrm{Fe}$, or needle-like $\mathrm{Al}_{3}(\mathrm{FeMn})$ easily transformed to the stable $\beta$-Fe phase after solution heat treatment $[17,18]$, which was similar to the results shown by Tseng et al. [9]. To inhibit the transformation from $\alpha$-Fe to $\beta$-Fe during the solution heat treatment, a high content of $\mathrm{Si}$ was employed in $\mathrm{Al}-6.5 \mathrm{Cu}-0.6 \mathrm{Mn}-0.5 \mathrm{Fe}$ alloy, however, the second intermetallics obviously agglomerated due to the precipitation of excess Si particles [11].

There exist two main kinds of intermetallics in 2219 wrought Al-Cu alloy, including Cu-rich intermetallics and Fe-rich intermetallics $[19,20]$. It is hard to prevent the formation of these intermetallics, since they may originate from (1) the content of $\mathrm{Cu}$ and Fe in 2219 $\mathrm{Al}-\mathrm{Cu}$ alloy is over the solubility limit of $\mathrm{Cu}$ in Al. (2) before being forged or rolled into desirable components for the propellant tanks of large launch vehicle, a cylindrical ingot must be supplied. Generally, the cooling rate ranges from 1 to $20 \mathrm{~K} \cdot \mathrm{s}^{-1}$. (3) the excess of $\mathrm{Mn}$ in $2219 \mathrm{Al}-\mathrm{Cu}$ alloy forms $\mathrm{Mn}$-rich compounds (named as $\mathrm{Al}_{20} \mathrm{Cu}_{2} \mathrm{Mn}_{3}$ ), which are mainly concentrated along the boundary during homogenization. The rod-like $\mathrm{Al}_{20} \mathrm{Cu}_{2} \mathrm{Mn}_{3}$ phase also can act as crack initiation sites during deformation, thereby deteriorating the ductility of the alloy. Thus, the nominal content of $\mathrm{Mn}$ is less than $0.4 \mathrm{wt} . \%$.

Therefore, it is necessary to refine these coarse particles to improve the mechanical properties of 2219 wrought Al-Cu alloy. The ultrasonic melt treatment has been successfully employed to manufacture large-scale 2219 aluminum alloy ingots by Li et al. [20-22]. They 
observed that the coarse constituents were modified and its area fraction could be decreased from the center $(69.07 \%)$ to the edge $(22.10 \%)$ in the ultrasonicated ingot. In the work of He et al. [1,23], the number of $\mathrm{Al}_{2} \mathrm{Cu}$ coarse particles was clearly decreased, and the characteristic of $\mathrm{Al}_{2} \mathrm{Cu}$ particles exhibited a more spheroidized shape with increasing the temperature of multi-directional forging. They also observed that increasing the cold predeformation before solution treatment can promote the dissolution of coarse $\mathrm{Al}_{2} \mathrm{Cu}$ particles during solution treatment and a similar phenomenon was reported in the literature [24]. Dong et al. [3] employed cryogenic deformation to $2219 \mathrm{Al}$ alloy forgings prior to solution treatment and found that the coarse $\mathrm{Al}_{2} \mathrm{Cu}$ particles were apt to dissolution because the cryogenic deformation caused more dislocation near the coarse particles. As a large number of dislocation formed around the particles during deformation, these particles could be in a higher energy state and were activated readily. In addition, dislocations also can act as fast channels for atomic diffusion. Thus, more coarse particles could dissolve into the matrix. All of these aforementioned conclusions were developed based on the refinement of the coarse $\mathrm{Al}_{2} \mathrm{Cu}$ particles. However, the evolution of Fe-rich intermetallic particles are rarely reported.

In the present work, we investigated the continuous evolution of Fe-rich intermetallic particles in 2219 wrought Al-Cu alloys as a function of Fe content across casting, homogenization, multidirectional forging (MDF), and solution-peak aging treatment. In addition, a comparative study of corresponding mechanical properties between casting, homogenization, MDF, and solution-peak aging treatment was carried out. Finally, the formation of Fe-rich intermetallic particles and correlation between these particles and tensile fracture behavior were discussed in detail.

\section{Materials and Methods}

The 2219 Al-Cu alloys with different Fe contents were melted in an electrical resistance furnace and the final chemical compositions were listed in Table 1 . The temperature of the melt was kept at $750-760{ }^{\circ} \mathrm{C}$, followed by gentle stirring, degassing by $\mathrm{C}_{2} \mathrm{Cl}_{6}$, and filtering. The temperature of the melt dropped and held at $720-730{ }^{\circ} \mathrm{C}$ for $30 \mathrm{~min}$, and then it was poured into a cylindrical steel mold with a diameter of $100 \mathrm{~mm}$. The as-cast alloys were firstly homogenized at $525 \pm 2{ }^{\circ} \mathrm{C}$ for $24 \mathrm{~h}$, and then cubic samples measuring $90 \mathrm{~mm} \times 90 \mathrm{~mm} \times 150 \mathrm{~mm}$ were cut off from the homogenized ingots. Subsequently, the samples were subjected to complex thermo-mechanical treatment (TMT) process, including 2 cycles of MDF by changing the axis through $90^{\circ}(X, Y, Z)$, adding solution treatment at $545 \pm 2{ }^{\circ} \mathrm{C}$ for $4 \mathrm{~h}$ in the middle of the MDF, and 1 pass of shape-forging with a height reduction of $50 \%$. Before the MDF process, the cubic samples were kept at $450{ }^{\circ} \mathrm{C}$ for $1.5 \mathrm{~h}$. The temperature of MDF was around $450 \pm 20{ }^{\circ} \mathrm{C}$ and the compression speed of MDF was $6 \mathrm{~mm} / \mathrm{s}$ by using a numerically controlled hydraulic press (YH27-500T; Hefei Forging Machine Co. Ltd., Hefei, China). The schematic diagram of the MDF process was shown in Figure 1. In each upset forging, the samples were compressed along different direction ( $A, B, C$ in order) at a forging ratio of 50\%. Then samples were flipped around the $Y$ axis and forced to stretch along the un-deformed direction. After MDF, the samples were solution-treated at $537 \pm 2{ }^{\circ} \mathrm{C}$ for $4 \mathrm{~h}$ and immediately quenched in water at room temperature, followed by cold pre-deformation by $3 \%$ and artificial aging at $165{ }^{\circ} \mathrm{C}$ for $24 \mathrm{~h}$.

Table 1. The actual chemical compositions of experimental alloys, wt.\%.

\begin{tabular}{lcccccccc}
\hline Sample No. & $\mathbf{C u}$ & $\mathbf{M n}$ & $\mathbf{F e}$ & $\mathbf{S i}$ & $\mathbf{M g}$ & $\mathbf{V}$ & $\mathbf{Z r}$ & $\mathbf{A l}$ \\
\hline 0.03 wt.\% Fe & 5.87 & 0.362 & 0.026 & $<0.0005$ & $\leq 0.02$ & 0.070 & 0.138 & Bal. \\
0.10 wt. $\% \mathrm{Fe}$ & 5.90 & 0.359 & 0.101 & $<0.0005$ & $\leq 0.02$ & 0.068 & 0.136 & Bal. \\
0.15 wt. $\% \mathrm{Fe}$ & 5.89 & 0.361 & 0.147 & $<0.0005$ & $\leq 0.02$ & 0.036 & 0.130 & Bal. \\
0.20 wt. $\% \mathrm{Fe}$ & 5.88 & 0.362 & 0.195 & $<0.0005$ & $\leq 0.02$ & 0.059 & 0.135 & Bal. \\
\hline
\end{tabular}




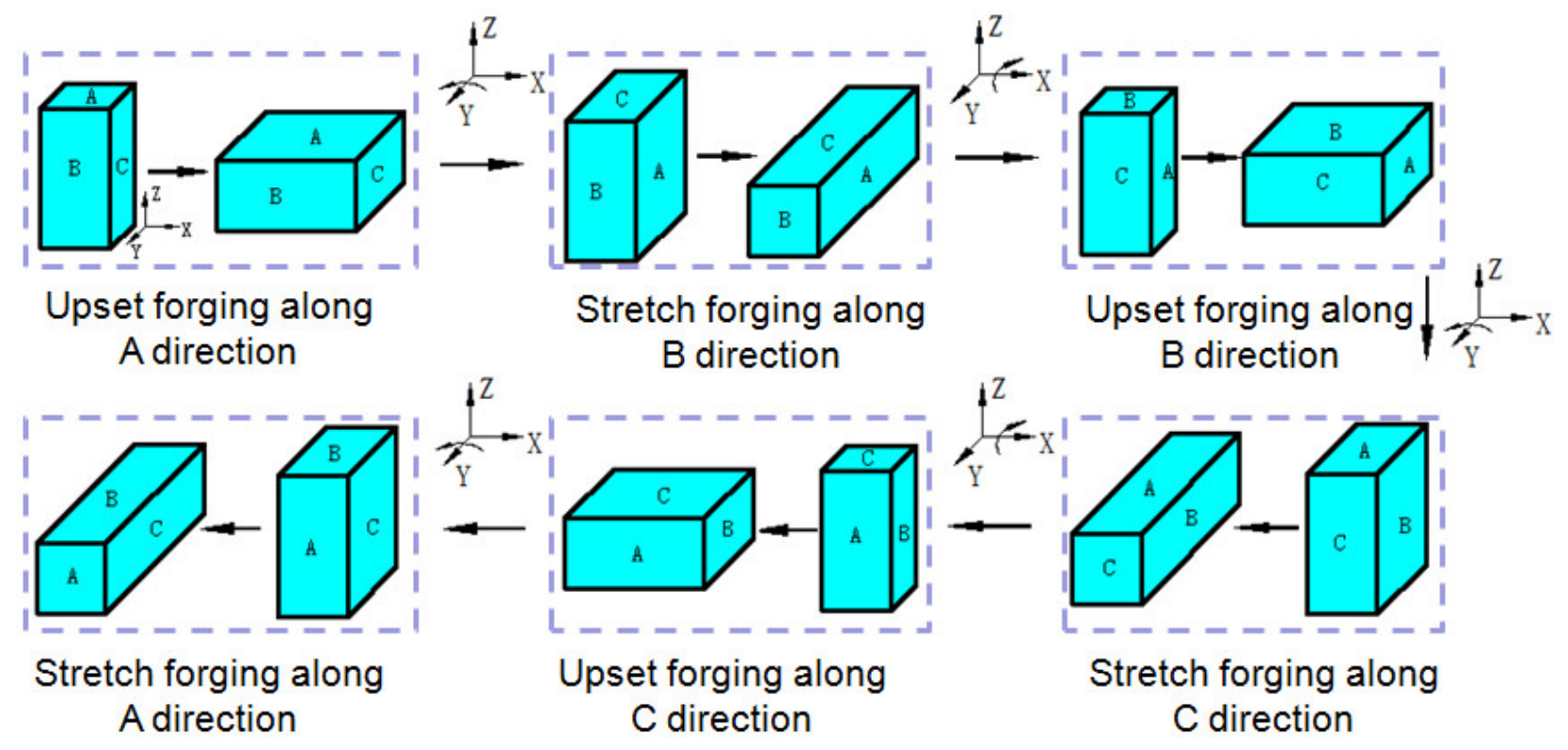

Figure 1. Schematic diagram of multidirectional forging (MDF) process.

The microstructures and fracture morphologies were examined by using a Leica DM4000M optical microscopy (OM; Leica Microsystems, Wizz, German) and a Nova Nano SEM230 scanning electron microscopy (SEM; FEI Co., Hillsboro, OR, USA) equipped with an energy dispersive X-ray spectrometer (EDS). After that, the size of the second-phase particles was the arithmetic mean of at least ten measured values using Image J analyzer software at the basis of ten SEM images from different positions for each sample. The tensile specimens were machined from different processing approaches according to the standard of GB/T228-2002. The gauge dimensions of tensile samples were $70 \mathrm{~mm}$ in length, $10 \mathrm{~mm}$ in width, and $2 \mathrm{~mm}$ in thickness. Following mechanical grinding, the tensile tests were performed in an Instron 3369 electronic universal testing machine (Instron Co., Canton, MA, USA) at room temperature. The extension was $2 \mathrm{~mm} / \mathrm{min}$. The data reported below were an average value of at least three independent tensile samples.

\section{Results}

\subsection{The Microstructure Evolution of Fe-Rich Intermetallics}

Figure 2 shows the microstructures of as-cast alloys with Fe content varying from 0.03 to 0.20 wt. \%. A typical dendrite features can be observed in all as-cast alloys, while a new phase obviously appeared as needle-like in $0.10 \mathrm{wt}$. \% Fe alloy. The black needle-like intermetallics were observed to increase significantly in both size and amount with the increase of Fe content from 0.1 to $0.2 \mathrm{wt}$ \% (as indicated by the arrows). To confirm these constituents (as marked by the crosses in Figure 2c), EDS was employed (as seen in Figure 3). The results indicated that the $\mathrm{Cu}$-rich intermetallics (Point $\mathrm{A}$ ) contained 71.74 at.\% $\mathrm{Al}$ and 28.26 at. $\% \mathrm{Cu}$, which agreed with the $\mathrm{Al}_{2} \mathrm{Cu}$ phase, while the composition of the needlelike phase (Point $\mathrm{B}$ ) was close to $\mathrm{Al}_{7} \mathrm{Cu}_{2}(\mathrm{Fe}, \mathrm{Mn})$. It is worth noticing that the needle-like $\mathrm{Al}_{7} \mathrm{Cu}_{2}(\mathrm{Fe}, \mathrm{Mn})$ phase mainly distributed across the dendrite, due to its formation through a peritectic reaction. 


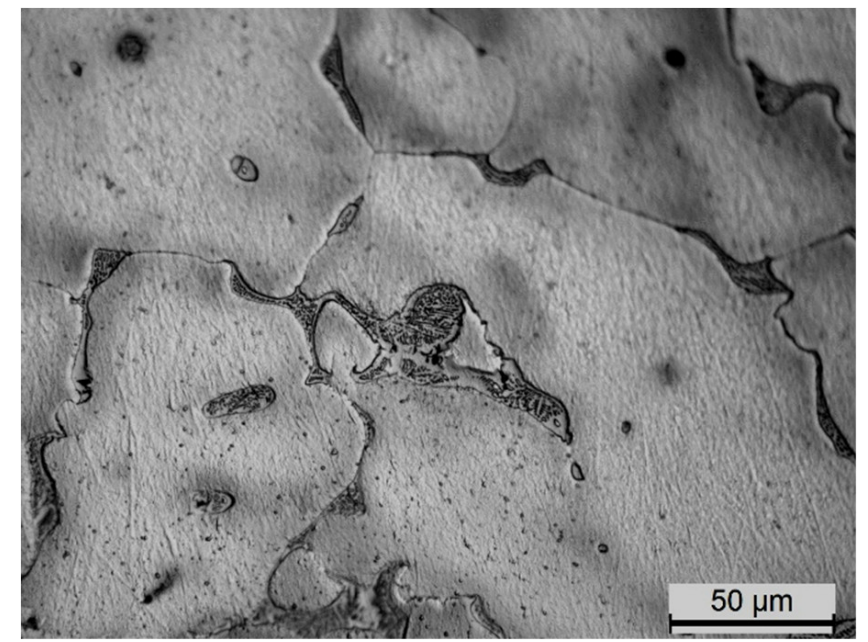

(a)

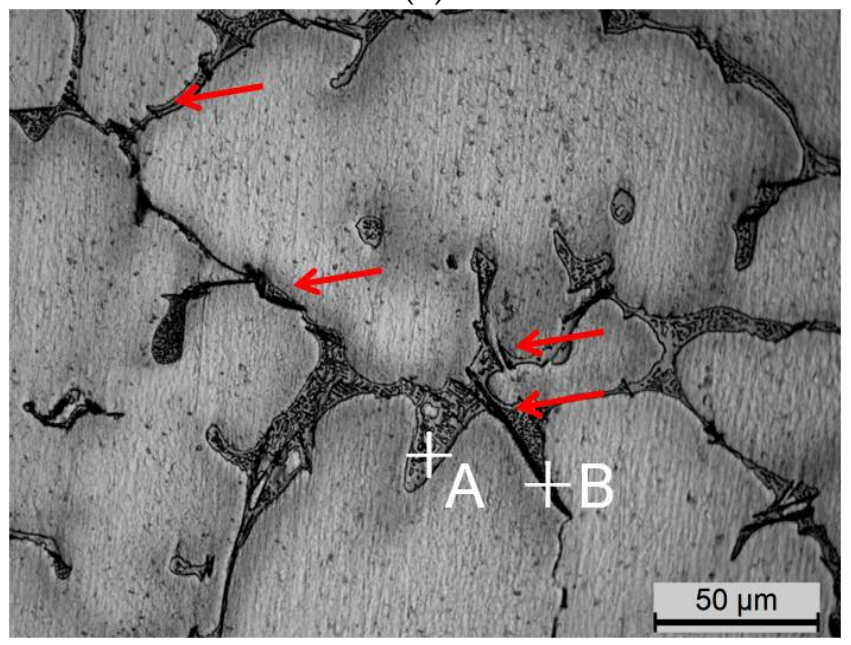

(c)

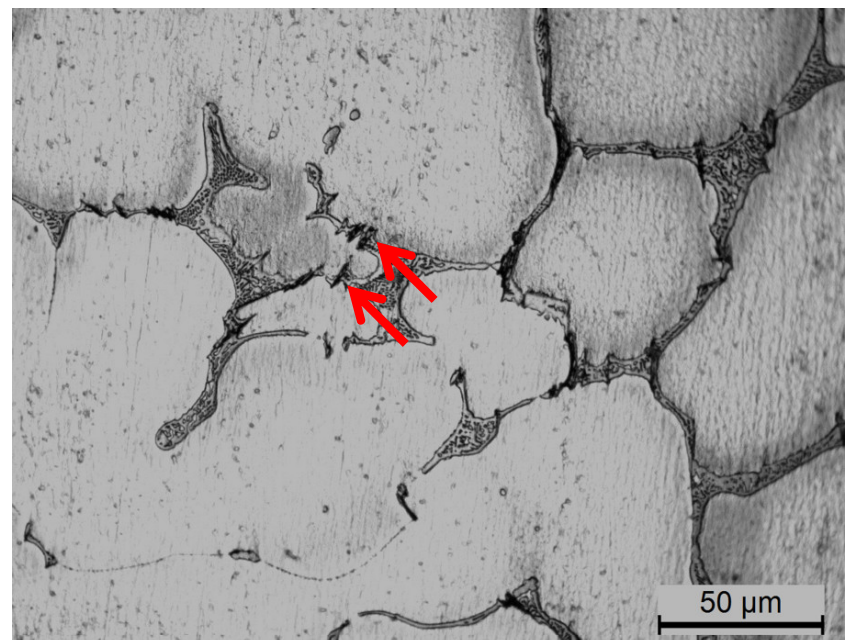

(b)

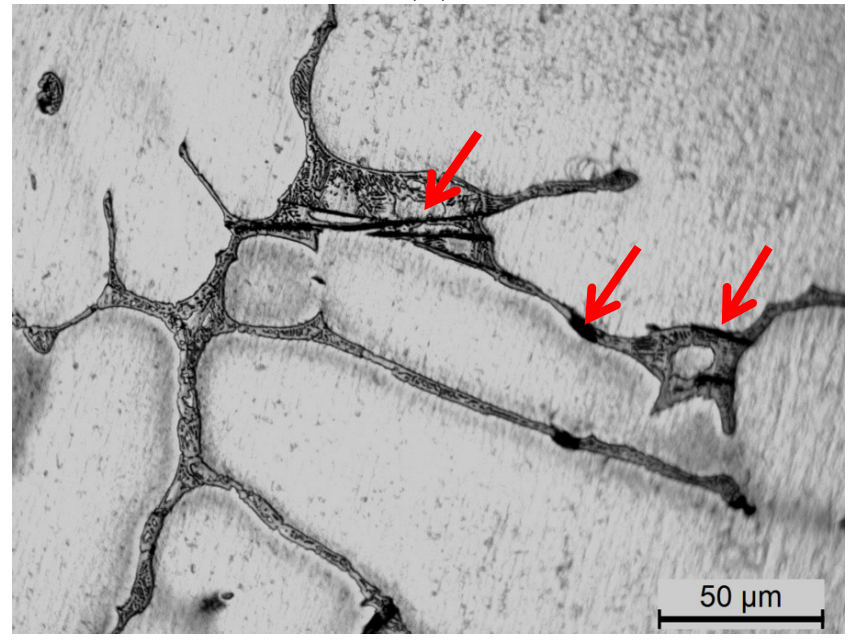

(d)

Figure 2. Microstructures of the as-cast alloys with different Fe contents: (a) 0.03 wt.\%; (b) 0.10 wt.\%; (c) 0.15 wt.\%; and (d) $0.20 \mathrm{wt} . \%$.

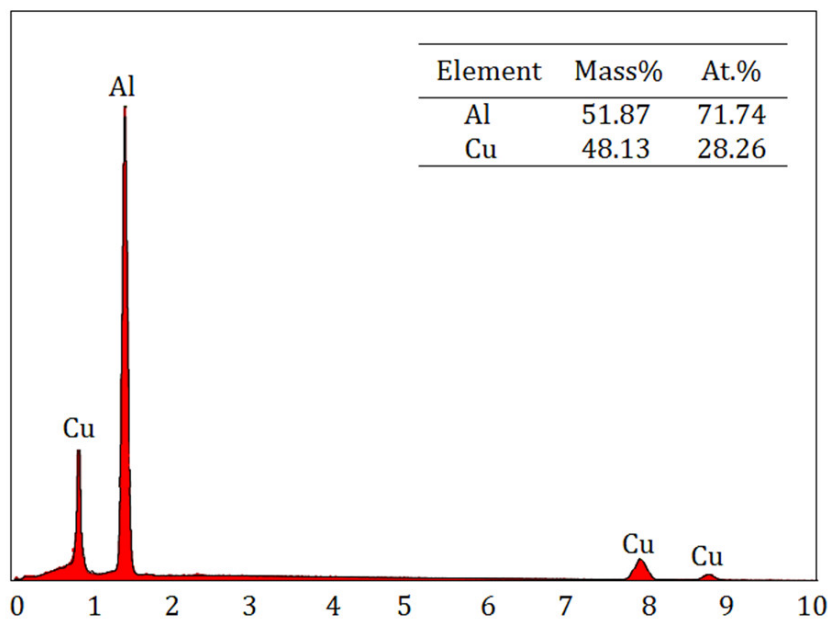

(a)

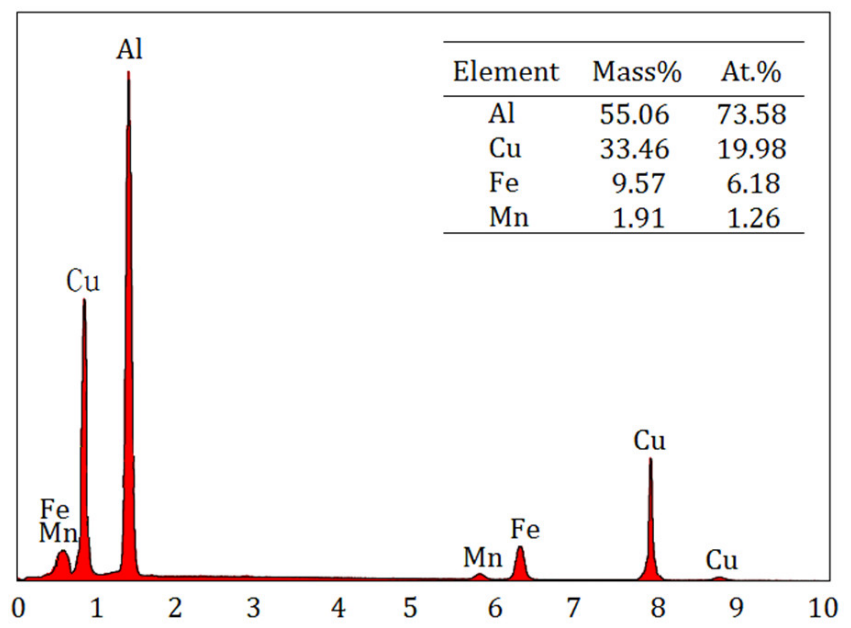

(b)

Figure 3. Energy dispersive $\mathrm{X}$-ray spectrometer (EDS) of the second-phase particles in as-cast 0.15 wt.\% Fe alloy: (a) Point A $\left(\mathrm{Al}_{2} \mathrm{Cu}\right)$ and (b) Point $\mathrm{B}\left(\mathrm{Al}_{7} \mathrm{Cu}_{2}(\mathrm{Fe}, \mathrm{Mn})\right)$. 
Figure 4 shows the microstructures of homogenized alloys with Fe content varying from 0.10 to $0.20 \mathrm{wt} . \%$. It can be seen that the dendrite features still existed, whereas they became thinner and clearer. However, the overall morphology of the needle-like $\mathrm{Al}_{7} \mathrm{Cu}_{2}(\mathrm{Fe}$, $\mathrm{Mn}$ ) intermetallics does not change (as seen in Figure 4d).

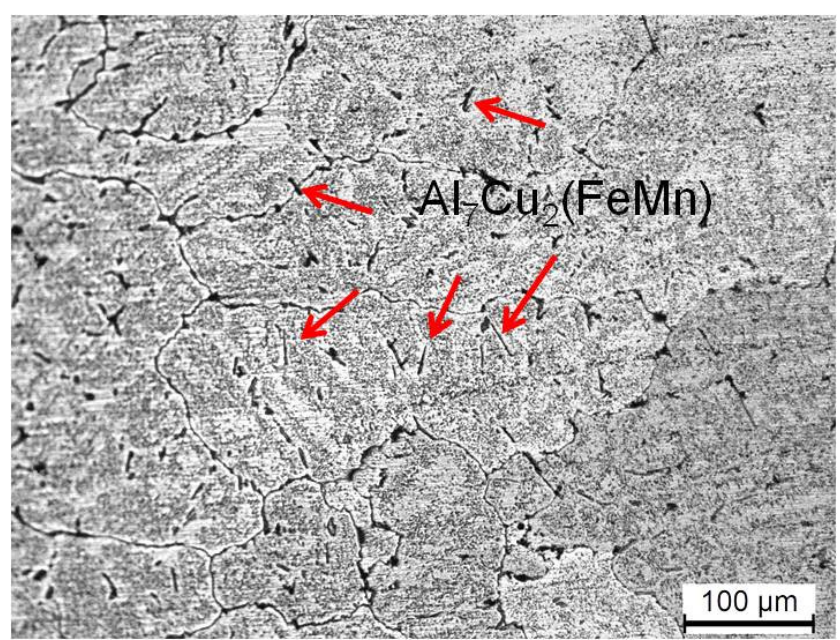

(a)

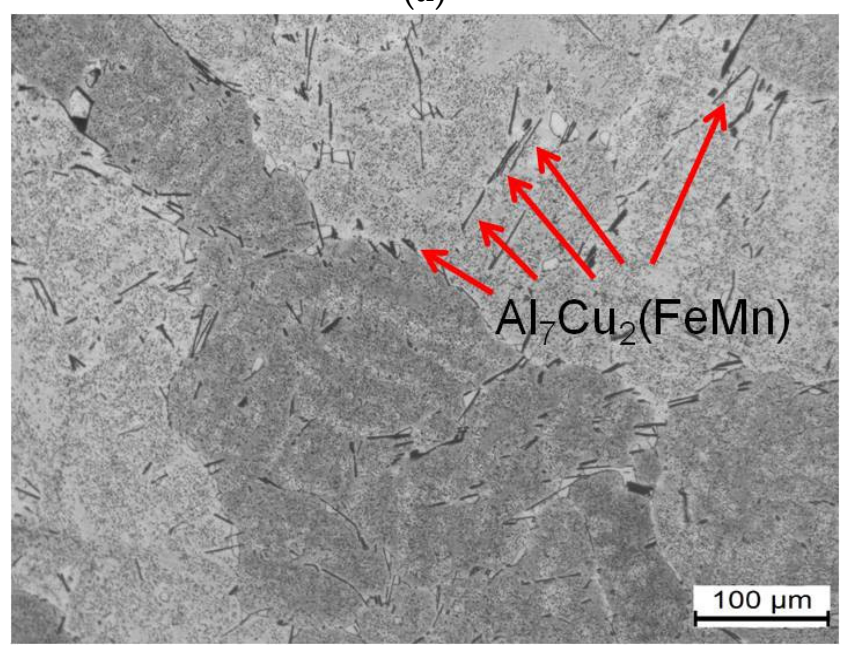

(c)

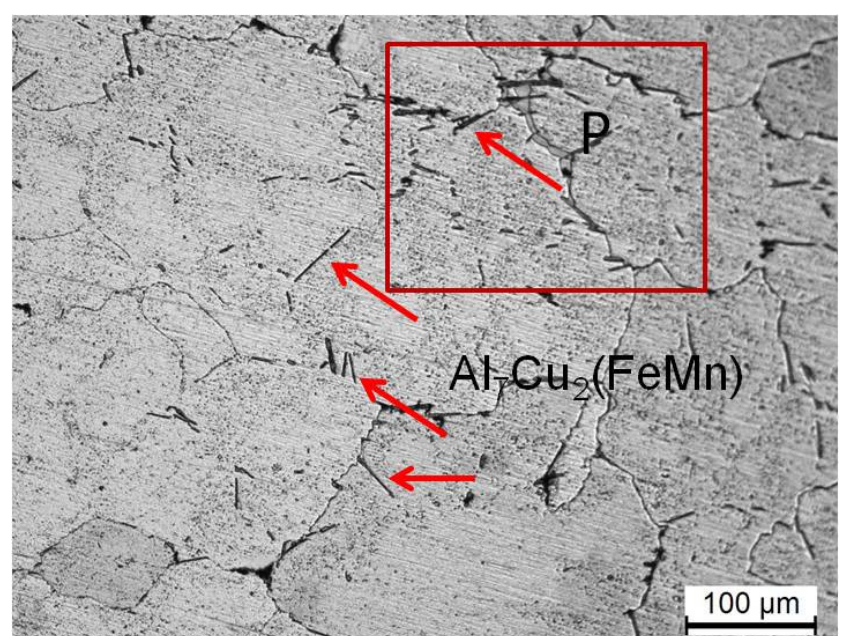

(b)

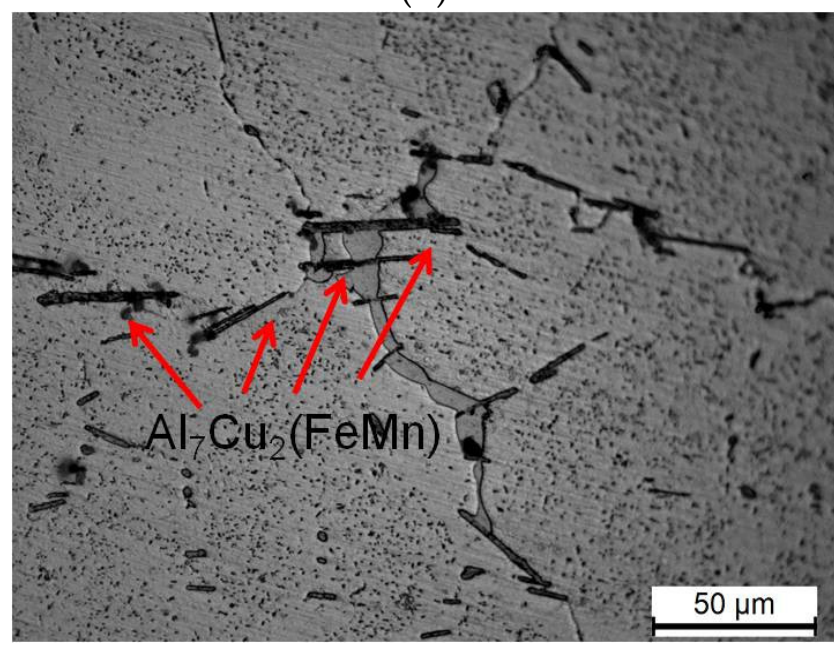

(d)

Figure 4. Microstructures of homogenized alloys with Fe contents: (a) 0.10 wt.\%; (b) 0.15 wt.\%; (c) 0.20 wt.\%; and (d) high-magnification at location P.

Figure 5 shows the microstructures of aged alloys with Fe content varying from 0.03 to $0.20 \mathrm{wt} . \%$. It can be seen that the average grain sizes were large and the un-dissolved coarse particles mainly exhibited inside the grain. Meanwhile, the amount and size of the coarse particles decreased obviously (as indicated by the arrows). During the multidirectional forging process, the coarse particles were subjected to stress concentration then can act as crack initiators because of the different elastic modulus of the coarse particle and its matrix counterpart. Moreover, the high density of dislocations can accumulate at their interfaces. These particles could be in a higher energy state and were activated readily, inducing the cracking of these coarse particles. Thus, the dynamic fragmentation of these coarse particles was expected to take place during forging. During the subsequent solution treatment, most of the fragmented $\mathrm{Al}_{2} \mathrm{Cu}$ particles were dissolved in the alloy matrix, while the $\mathrm{Al}_{7} \mathrm{Cu}_{2}(\mathrm{Fe}, \mathrm{Mn})$ particles were un-dissolved in the alloy matrix due to the different solubility of $\mathrm{Cu}$ and $\mathrm{Fe}$ in the $\mathrm{Al}$ matrix. 


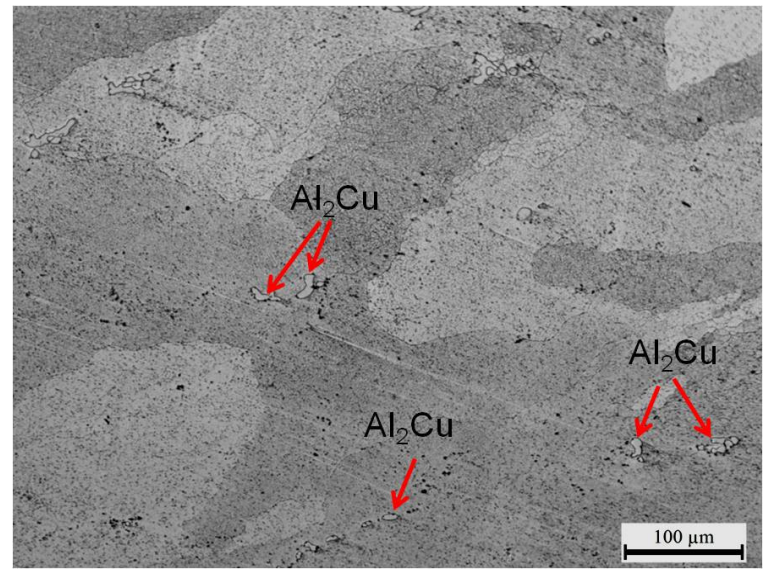

(a)

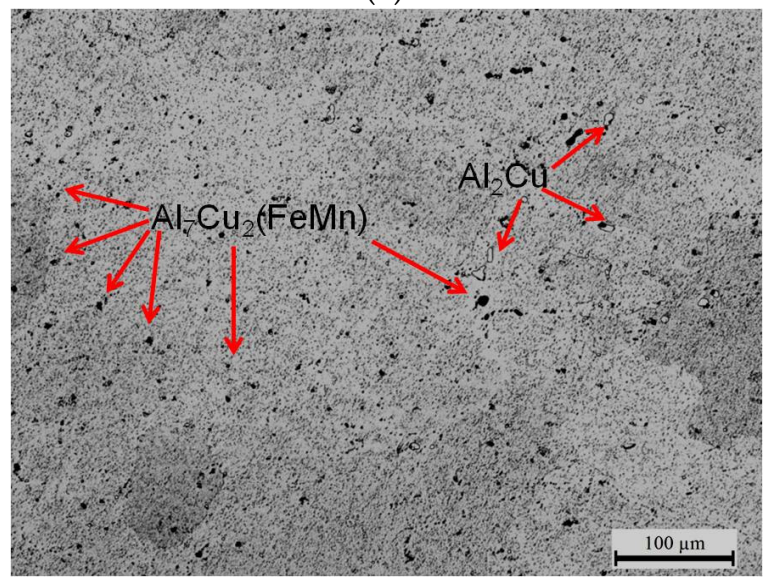

(c)

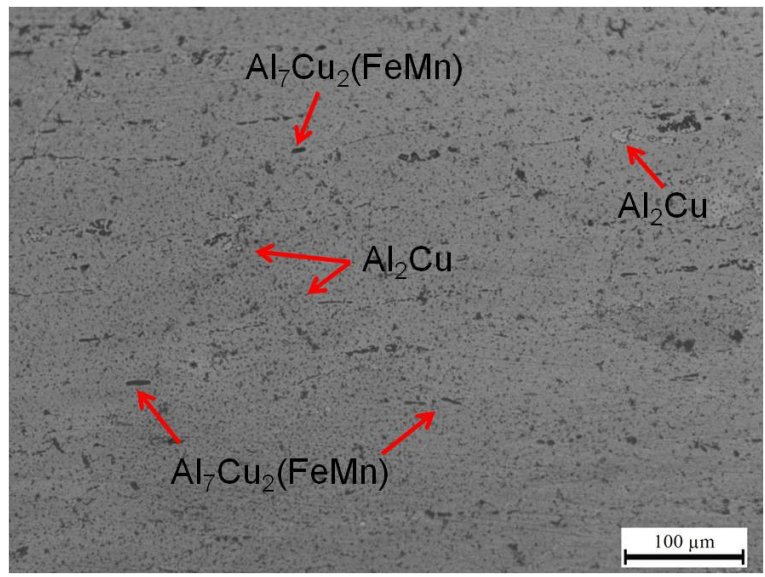

(b)

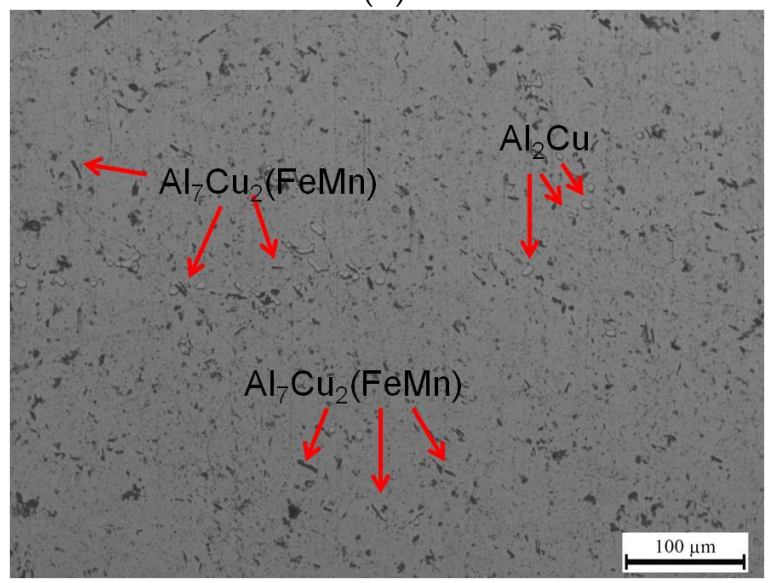

(d)

Figure 5. Microstructures of aged alloys with Fe contents: (a) 0.03 wt.\%; (b) 0.1 wt.\%; (c) 0.15 wt.\%; and (d) 0.2 wt.\%.

In order to evaluate the un-dissolved particles, the microstructures of aged alloys with different Fe contents were further observed by SEM, as shown in Figure 6. The corresponding EDS analysis as shown in Table 2 reveals that the more granular particles were $\mathrm{Al}_{2} \mathrm{Cu}$ phase (as marked by point $\mathrm{A}$ and $\mathrm{D}$ ) and the rod-like particles with sharp edges were $\mathrm{Al}_{7} \mathrm{Cu}_{2}(\mathrm{Fe}, \mathrm{Mn}$ ) phase (as marked by point $\mathrm{B}$ and $\mathrm{C}$ in Figure 6 ). The reason was that compressive stress can be exerted on $\mathrm{Al}_{2} \mathrm{Cu}$ and $\mathrm{Al}_{7} \mathrm{Cu}_{2}(\mathrm{Fe}, \mathrm{Mn})$ particles during multidirectional forging process, then the particle can be fragmented when the applied stress was greater than its strength limit. In the subsequent solution treatment, partial $\mathrm{Al}_{2} \mathrm{Cu}$ particles would be dissolved into the $\mathrm{Al}$ matrix, however, the fragmented $\mathrm{Al}_{7} \mathrm{Cu}_{2}(\mathrm{Fe}$, $\mathrm{Mn}$ ) particles could not be dissolved into the $\mathrm{Al}$ matrix due to the insolubility of Fe in $\mathrm{Al}-\mathrm{Cu}$ alloy. Namely, compared with the refinement mechanism of $\mathrm{Al}_{2} \mathrm{Cu}$ particles, only fragmentation took place in $\mathrm{Al}_{7} \mathrm{Cu}_{2}(\mathrm{Fe}, \mathrm{Mn})$ particles.

Table 2. SEM-EDS analysis results of the un-dissolved particles shown in Figure 6 (at. \%).

\begin{tabular}{ccccc}
\hline \multirow{2}{*}{ Point } & \multicolumn{5}{c}{ Elements } \\
\cline { 2 - 5 } & Al & Cu & Fe & Mn \\
\hline A & 67.96 & 32.04 & - & - \\
B & 71.01 & 20.62 & 6.64 & 1.73 \\
C & 73.28 & 17.42 & 7.61 & 1.69 \\
D & 72.54 & 27.46 & - & - \\
\hline
\end{tabular}




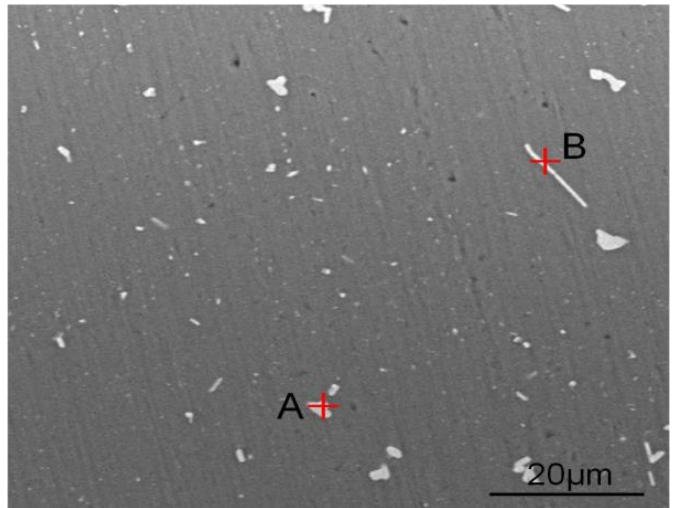

(a)

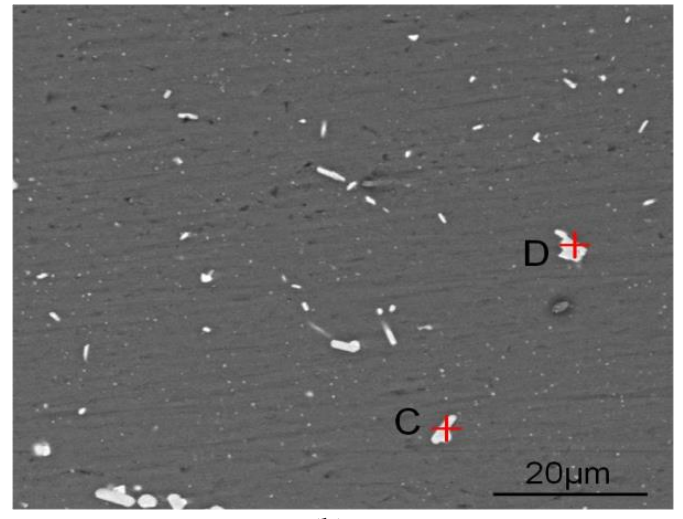

(b)

Figure 6. Scanning electron microscopy (SEM) images of aged alloys with Fe contents: (a) 0.10 wt.\% and (b) 0.20 wt.\%.

Figure 7 shows the Transmission electron microscopy (TEM) images and corresponding diffraction spots of aged alloys with Fe contents. As seen from the diffraction spots, there were two kinds of perpendicular precipitates, named as $\theta^{\prime}$ phase (coarse precipitates with a mean length of $\sim 99 \mathrm{~nm}$ ) and $\theta^{\prime \prime}$ phase (fine precipitates with a mean length of $\sim 26 \mathrm{~nm}$ ), respectively. It was found that the number and size of these two precipitates did not change obviously with the increase of impurity Fe content. Calculated carefully by the particle-diameter analysis software, the area fraction of the precipitates reduced from $6.5 \%$ to $6.1 \%$ with increasing the Fe content from 0.03 to $0.20 \mathrm{wt} . \%$. Compared with the tensile tested results with different Fe contents, the change of Fe content had little influence on strength, as shown in Figure 8.

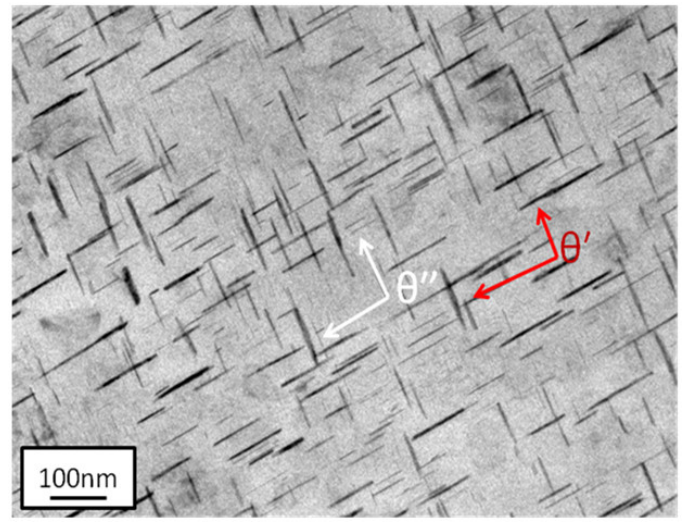

(a)

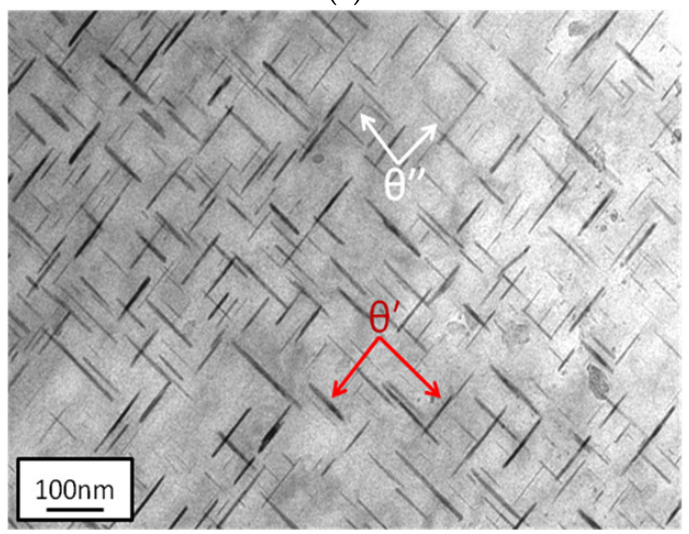

(c)

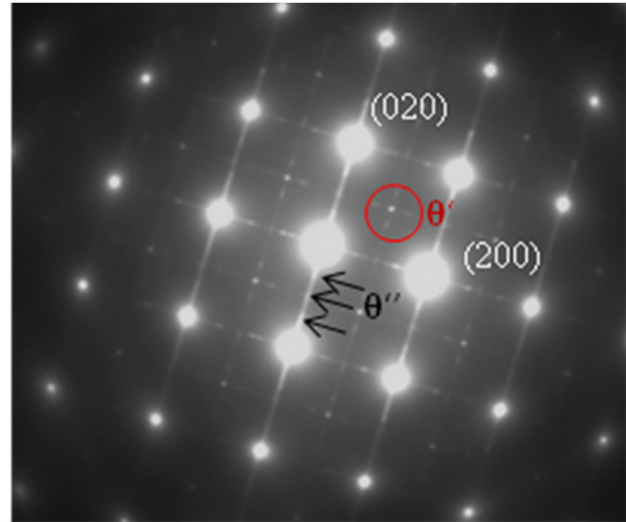

(b)

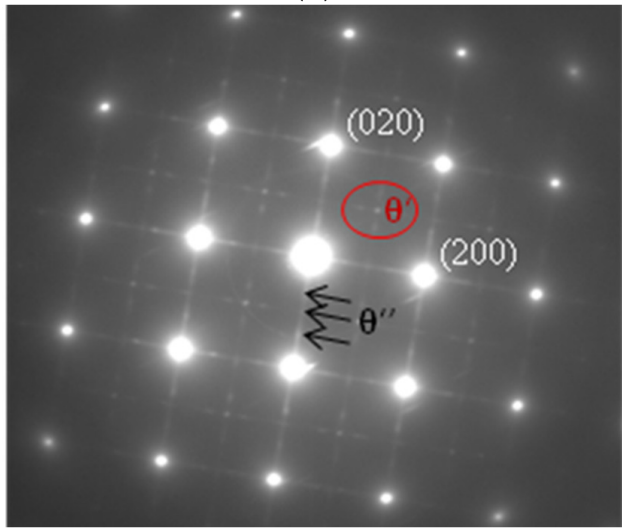

(d)

Figure 7. Transmission electron microscopy (TEM) images and corresponding diffraction spots obtained along the (100) $\mathrm{Al}$ zone axis of aged alloys with Fe contents: (a,b) 0.03 wt.\% and (c,d) 0.20 wt.\%. 


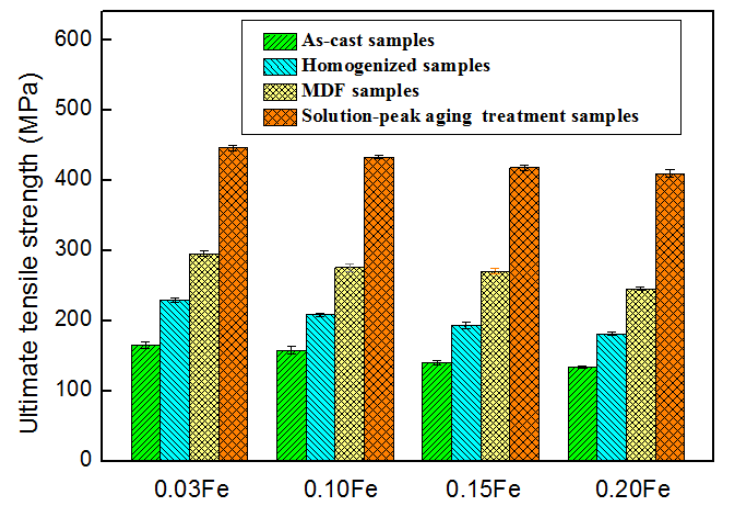

(a)

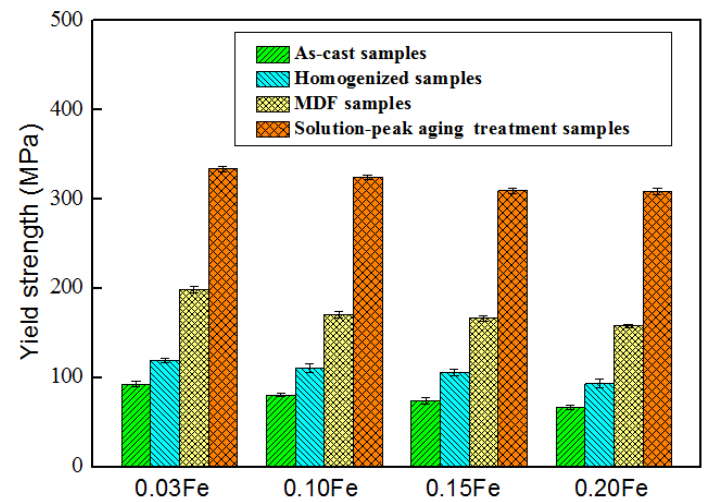

(b)

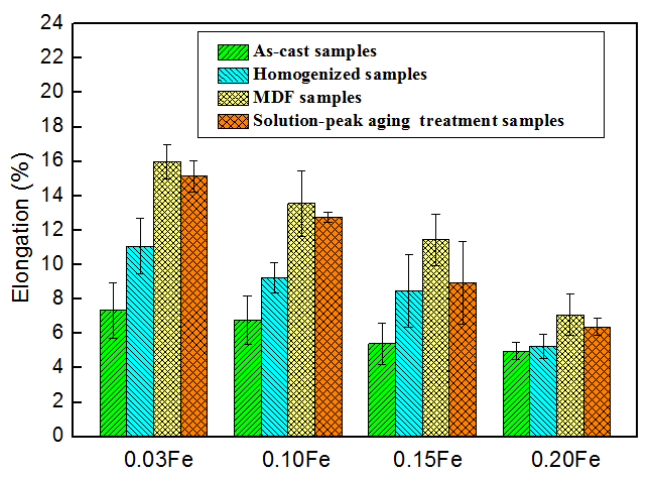

(c)

Figure 8. Mechanical properties of $2219 \mathrm{Al}-\mathrm{Cu}$ alloys with different processes: (a) The ultimate tensile strength; (b) the yield strength; (c) elongation.

\subsection{Mechanical Properties and Tensile Fracture Morphology}

Figure 8 illustrates the mechanical properties against different processing approaches, i.e., as-cast, homogenization, $\mathrm{MDF}$, and solution-peak aging treatment. All of the samples show the same trend of ultimate tensile strength (UTS), yield strength (YS), and elongation (EL) variation from the processes of as-cast to peak aging stage. It also can be seen that under the same processing condition, similar tendency of UTS, YS, and EL variation with increasing the Fe content. The as-cast samples presented relatively low values of UTS/YS/EL, i.e., 165.35/92.56 MPa and 7.34\% for $0.03 \mathrm{wt} . \%$ Fe alloy, 157.61/80.67 MPa and $6.79 \%$ for $0.10 \mathrm{wt} . \%$ Fe alloy, $140.29 / 74.44 \mathrm{MPa}$ and $5.41 \%$ for $0.15 \mathrm{wt} . \%$ Fe alloy, and $133.77 / 66.52 \mathrm{MPa}$ and $4.98 \%$ for $0.20 \mathrm{wt} . \%$ Fe alloy. The UTS/YS/EL values of all as-homogenized samples increased slightly compared with cast process. For MDF samples, the UTS/YS values continued to rise slightly, while the maximum EL values were observed to be $15.99 \%, 13.56 \%, 11.46 \%$, and $7.09 \%$ corresponding to the Fe contents of $0.03,0.10,0.15$, and $0.20 \mathrm{wt} . \%$, respectively. The solution-peak aging treatment significantly increased the UTS/YS values by at least $270 / 90 \mathrm{MPa}$, respectively, compared with the as-cast condition. For peak aging samples, the UTS and YS decreased slightly from 445.64 to $432.87 \mathrm{MPa}$ (an decrease by $2.87 \%$ ) and 333.76 to $324.36 \mathrm{MPa}$ (a decrease by $2.81 \%$ ) respectively, and the EL decreased remarkably from 15.14 to $12.76 \%$ (a decrease by $15.71 \%$ ) with an increase in Fe content from 0.03 to $0.10 \mathrm{wt} . \%$. Further increasing the Fe content to $0.20 \mathrm{wt} . \%$, the UTS and YS decreased to 409.34 and $308.29 \mathrm{MPa}$, respectively, and the EL reduced to $6.37 \%$. The UTS, YS, and EL decreased by $36 \mathrm{MPa}, 25 \mathrm{MPa}$, and $57.92 \%$, respectively, which compared to the respective values of the $0.03 \mathrm{wt} . \%$ Fe alloy.

Figure 9 shows the tensile fracture morphology of aged alloys with different Fe contents. It can be seen that the fracture of tensile specimens with $0.03 \mathrm{wt} . \%$ Fe was predominantly dominated by inter-granular fracture (as seen in Figure 9a). Higher magnification observations of a rough surface (as marked by the ellipse in Figure 9a), trans-granular frac- 
ture caused by the particle-matrix interface decohesion also existed, as shown in Figure 9b. The dimples around the fine spherical $\mathrm{Al}_{2} \mathrm{Cu}$ particles were considerably shallow in the size less than $6 \mathrm{um}$. As the Fe content increased to $0.10 \mathrm{wt} . \%$, a typical bimodal dimple size distribution was observed on the rough surface and the main fracture mode was diverted to trans-granular fracture, as shown in Figure 9c. The first population of dimples, named as larger primary dimples, were formed by the fracture of Fe-rich constituent particles, whereas the other population of dimples with finer sizes occupied the ligaments between the primary dimples were the result of particle-matrix interface de-cohesion. The similar fracture feature was found in the tensile specimen with $0.20 \mathrm{wt} . \%$ Fe (as seen in Figure 9d). However, the population of primary dimples caused by coarse constituent particles was observed to be more and the size of partial dimples increased to $20 \mu \mathrm{m}$. In brief, with an increase in Fe content, the un-dissolved Fe-rich impurity particles increased as a result, and tended to crack formation because a higher stress concentration existed at the larger particles during deformation, which was in accord with the tensile tested results.

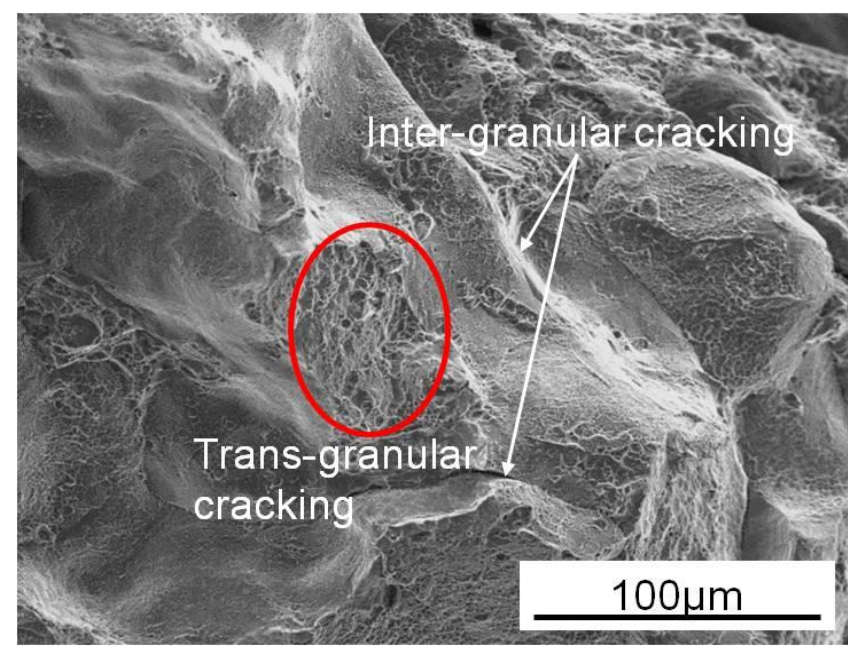

(a)

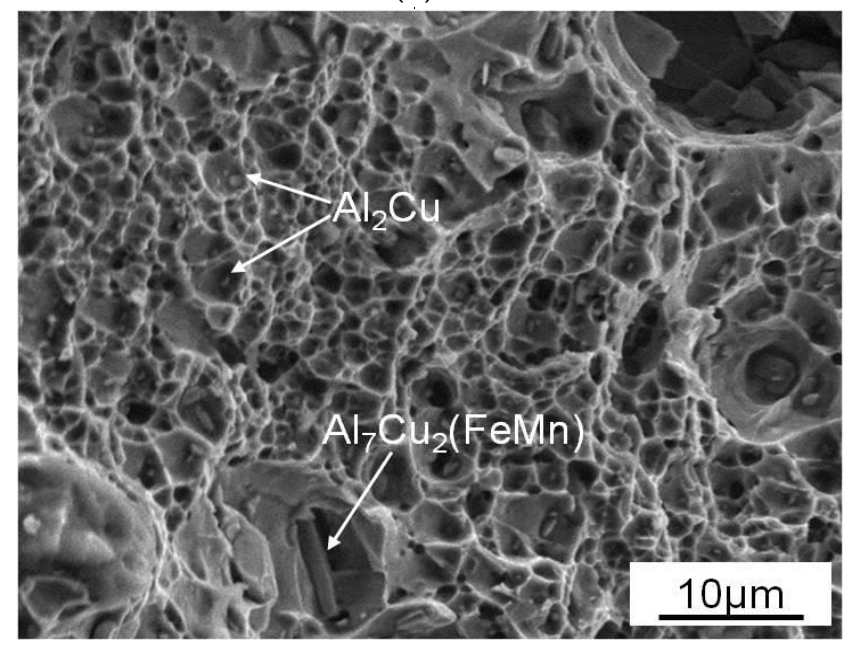

(c)

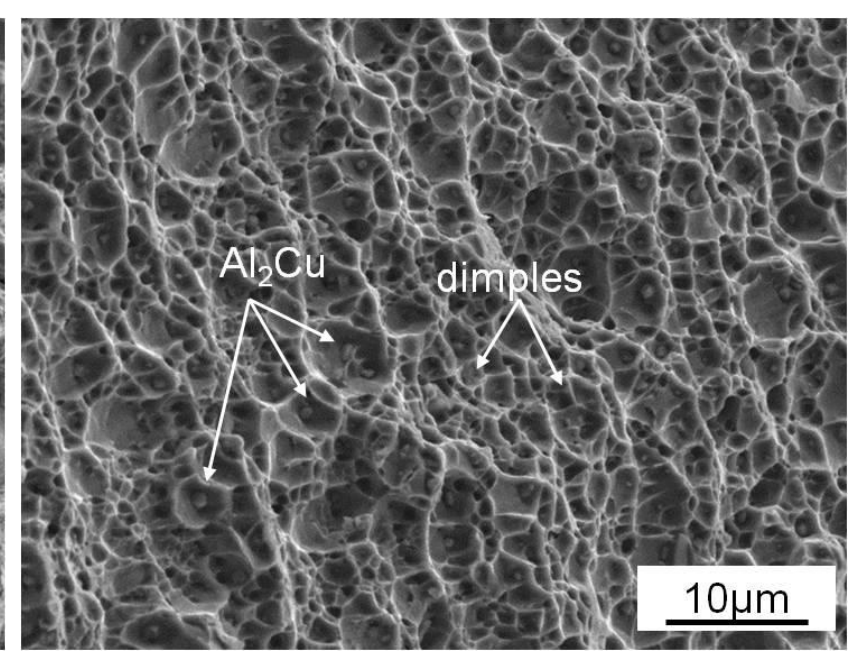

(b)

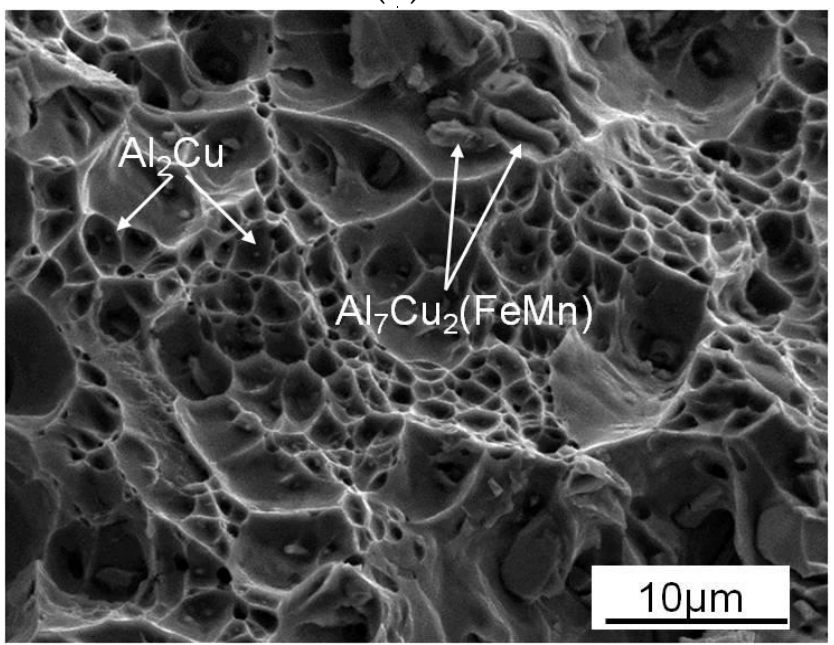

(d)

Figure 9. Fracture morphology of aged alloy with different Fe contents. (a,b) 0.03 wt.\%; (c) 0.10 wt. $\%$; and (d) 0.20 wt.\%.

\section{Discussion}

\subsection{Fe-Rich Intermetallics Analysis}

Referring to Al-Cu-Fe-Mn quaternary phase diagram [25] (as indicated in Figure 10), it can be seen that the Fe-rich phases including $\mathrm{Al}_{3} \mathrm{Fe}, \mathrm{Al}_{6}(\mathrm{FeMn})$ and $\mathrm{Al}_{7} \mathrm{Cu}_{2} \mathrm{Fe}$ phases may appear in Al-Cu cast alloys. For the $2219 \mathrm{Al}-\mathrm{Cu}$ alloy, the solubility of $\mathrm{Mn}$ in Al-Cu alloy 
can reach $2 \%$, form a supersaturate solid solution as a result, which leads to the formation of $\mathrm{Al}_{20} \mathrm{Mn}_{3} \mathrm{Cu}_{2}$ dispersoids during homogenization. With the increasing of Fe content to a certain extent, the solubility of $\mathrm{Mn}$ in $\mathrm{Al}-\mathrm{Cu}$ alloy significantly reduces and $\mathrm{Al}_{6}(\mathrm{FeMn})$ phase can form readily, which is in line with the results calculated by software JMatPro 7, as shown in Figure 11. This phenomenon was related to the strong segregation tendency of Fe. Since the solubility of Fe in Al-Cu alloy is quite low, almost all of the Fe segregates to the interface front during solidification and combines with a small amount of $\mathrm{Mn}$ to form $\mathrm{Al}_{6}(\mathrm{FeMn})$ by eutectic reaction $\left(\mathrm{L} \rightarrow \alpha-\mathrm{Al}+\mathrm{Al}_{6}(\mathrm{FeMn})\right)$. With a further increase in the content of $\mathrm{Fe}$, the amounts of $\mathrm{Al}_{6}(\mathrm{FeMn})$ increase, meanwhile, the temperature of eutectic reaction also rises (from about 577 to $608{ }^{\circ} \mathrm{C}$ ), as shown in Figure $11 \mathrm{~b}-\mathrm{d}$. But no $\mathrm{Al}_{6}(\mathrm{FeMn}$ ) phase existed in $2219 \mathrm{Al}-\mathrm{Cu}$ alloy (as shown in Figure 3), which would be explained by the solid-state transformation from $\mathrm{Al}_{6}(\mathrm{FeMn})$ phase into $\mathrm{Al}_{7} \mathrm{Cu}_{2} \mathrm{Fe}$ or $\mathrm{Al}_{7} \mathrm{Cu}_{2}(\mathrm{Fe}, \mathrm{Mn})$ phase during solidification, as shown in Table 3. As a result, the $\mathrm{Al}_{7} \mathrm{Cu}_{2} \mathrm{Fe}$ or $\mathrm{Al}_{7} \mathrm{Cu}_{2}(\mathrm{Fe}, \mathrm{Mn})$ phases increased with the increase of the Fe content. In addition, the content of impurity Fe in $2219 \mathrm{Al}-\mathrm{Cu}$ alloy is generally controlled below $0.30 \mathrm{wt} . \%$. So, only needle-like $\mathrm{Al}_{7} \mathrm{Cu}_{2} \mathrm{Fe}$ or $\mathrm{Al}_{7} \mathrm{Cu}_{2}(\mathrm{Fe}, \mathrm{Mn})$ phase in $2219 \mathrm{Al}-\mathrm{Cu}$ cast alloy, which is agreement with the reference of Tseng et al. $[7,21]$.

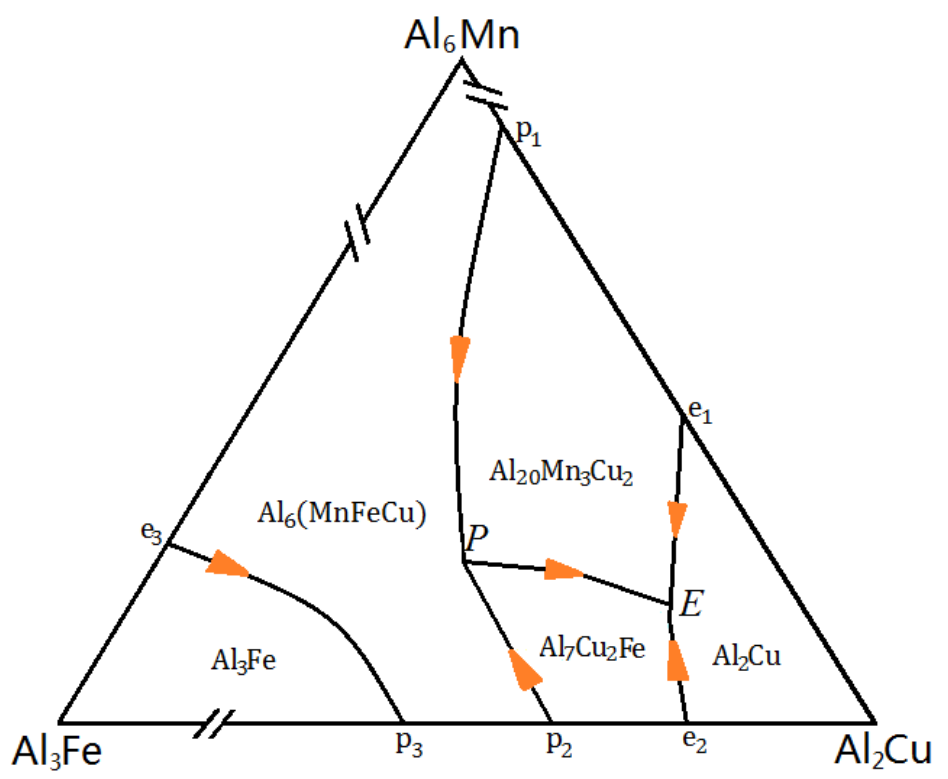

Figure 10. Phase diagram of intermetallics Al-Cu-Fe-Mn system alloy, reproduced from [25], with permission of Elsevier, 2005.

Table 3. The possible solidification reactions in 2219 Al-Cu alloys.

\begin{tabular}{cc}
\hline Reactions & T $\left({ }^{\circ} \mathbf{C}\right)$ \\
$\mathrm{L} \rightarrow \alpha-\mathrm{Al}$ & $651-648$ \\
$\mathrm{~L} \rightarrow \alpha-\mathrm{Al}+\mathrm{Al}_{6}(\mathrm{FeMn})$ & $608-577$ \\
$\mathrm{~L}+\mathrm{Al}_{6}(\mathrm{FeMn}) \rightarrow \alpha-\mathrm{Al}+\mathrm{Al}_{20} \mathrm{Mn}_{3} \mathrm{Cu}_{2}+\mathrm{Al}_{7} \mathrm{Cu}_{2} \mathrm{Fe}$ & $597-576$ \\
$\mathrm{~L} \rightarrow \alpha-\mathrm{Al}+\mathrm{Al}_{20} \mathrm{Mn}_{3} \mathrm{Cu}_{2}+\mathrm{Al}_{7} \mathrm{Cu}_{2} \mathrm{Fe}$ & $587-537$ \\
$\mathrm{~L} \rightarrow \alpha-\mathrm{Al}+\mathrm{Al}_{2} \mathrm{Cu}+\mathrm{Al}_{20} \mathrm{Mn}_{3} \mathrm{Cu}_{2}+\mathrm{Al}_{7} \mathrm{Cu}_{2} \mathrm{Fe}$ & $547-540$ \\
\hline
\end{tabular}




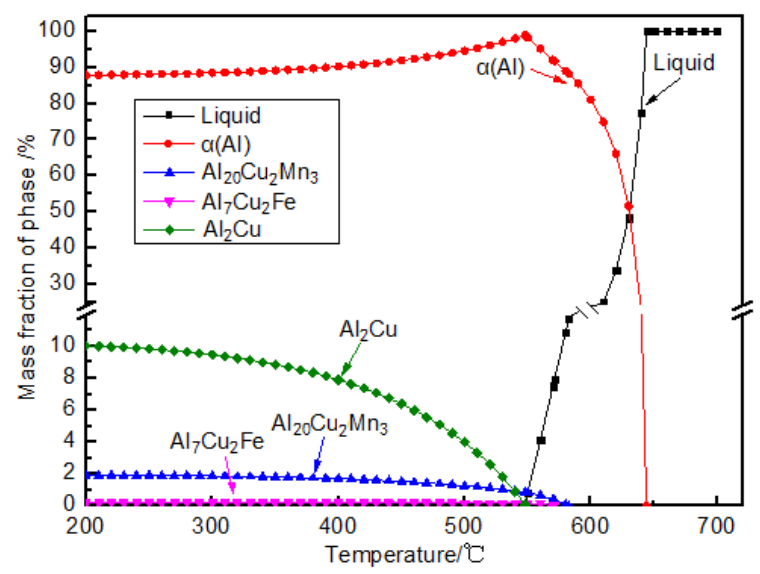

(a)

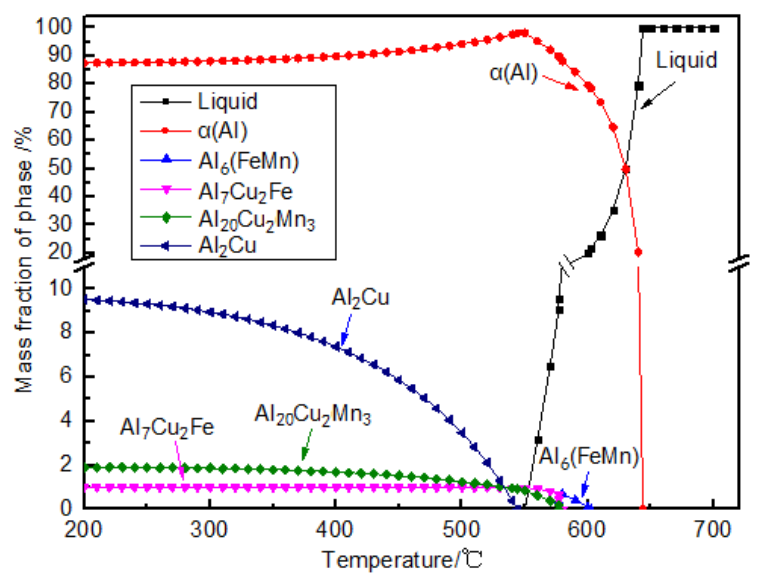

(c)

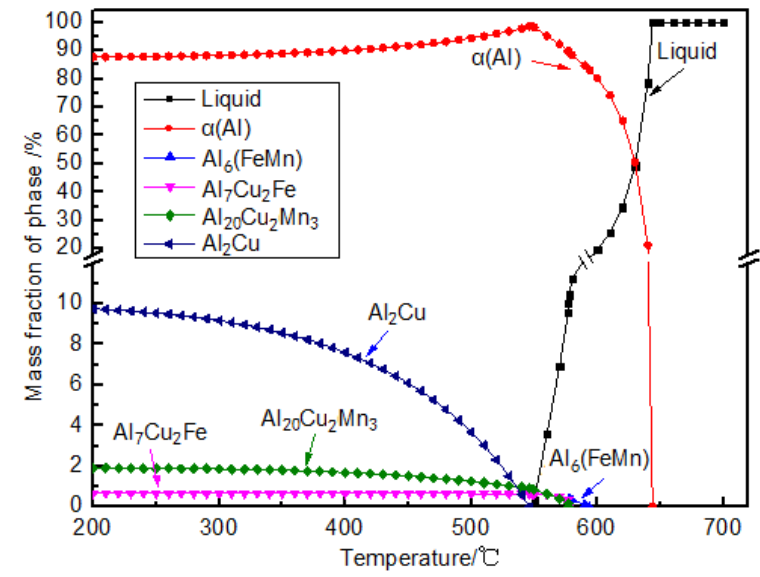

(b)

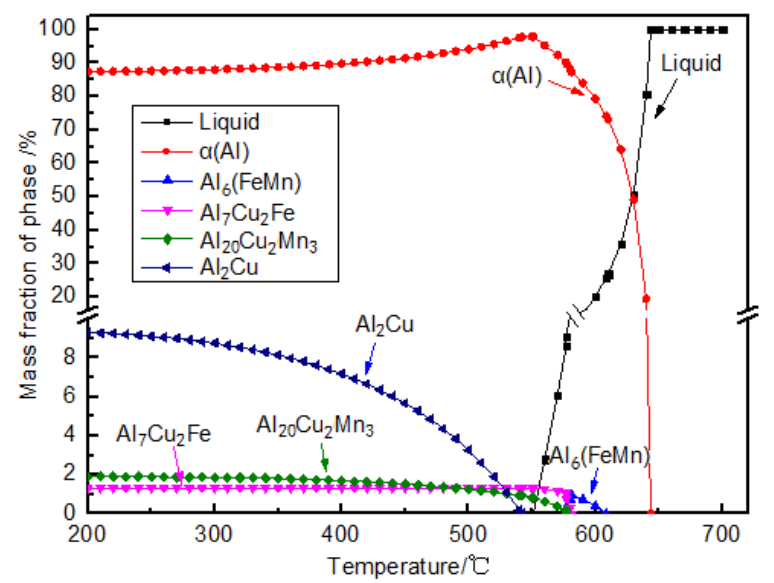

(d)

Figure 11. Phase fraction vs. temperature curves of $2219 \mathrm{Al}-\mathrm{Cu}$ alloy with different Fe contents calculated by the software JMatPro 7: (a) 0.03 wt.\%; (b) 0.1 wt.\%; (c) 0.15 wt.\%; and (d) 0.2 wt.\%.

Based on the Al-Cu-Fe-Mn quaternary phase diagram (as seen in Figure 10), the calculation results by the software JMatPro 7 (seen in Figure 11), the metallographic observations with SEM, and those reported by Liu et al. [13,26,27], the possible solidification reactions are listed in Table 3 . During the solidification, the liquid alloys are nucleated at about $648-651{ }^{\circ} \mathrm{C}$ and the $\alpha$-Al dendrite network forms, then the eutectic and peritectic reactions shall take place. If there is only a small amount of Fe existing in Al-Cu-Mn alloy, the solidification ends with the formation of $\mathrm{Al}_{7} \mathrm{Cu}_{2} \mathrm{Fe}, \mathrm{Al}_{2} \mathrm{Cu}$, and $\mathrm{Al}_{20} \mathrm{Mn}_{3} \mathrm{Cu}_{2}$ though the ternary eutectic reactions $\mathrm{L} \rightarrow \alpha-\mathrm{Al}+\mathrm{Al}_{2} \mathrm{Cu}+\mathrm{Al}_{20} \mathrm{Mn}_{3} \mathrm{Cu}_{2}\left(\mathrm{e}_{1}-\mathrm{E}\right.$ line $)$ and $\mathrm{L} \rightarrow \alpha-\mathrm{Al}+$ $\mathrm{Al}_{2} \mathrm{Cu}+\mathrm{Al}_{7} \mathrm{Cu}_{2} \mathrm{Fe}\left(\mathrm{e}_{2}-\mathrm{E}\right.$ line). However, the amount of $\mathrm{Al}_{7} \mathrm{Cu}_{2} \mathrm{Fe}$ phase was too small to be found in 0.03 wt. $\%$ Fe cast alloy (as shown in Figure 2a). With the increasing of Fe content to $0.10 \mathrm{wt} . \%, \mathrm{Al}_{6}(\mathrm{FeMn})$ intermetallic phase shall precipitate firstly at about $600{ }^{\circ} \mathrm{C}$, and then the peritectic transformation $\mathrm{L}+\mathrm{Al}_{6}(\mathrm{FeMn}) \rightarrow \alpha-\mathrm{Al}+\mathrm{Al}_{20} \mathrm{Mn}_{3} \mathrm{Cu}_{2}+\mathrm{Al}_{7} \mathrm{Cu}_{2} \mathrm{Fe}\left(\mathrm{p}_{1}-\mathrm{P}\right.$ line or $\mathrm{p}_{2}-\mathrm{P}$ line) leads to form the $\mathrm{Al}_{7} \mathrm{Cu}_{2} \mathrm{Fe}$ intermetallics, which always distribute across the dendrite network (as shown in Figure $2 b$ ). The solidification ends with the formation of the eutectic reactions $\mathrm{L} \rightarrow \alpha-\mathrm{Al}+\mathrm{Al}_{2} \mathrm{Cu}+\mathrm{Al}_{20} \mathrm{Mn}_{3} \mathrm{Cu}_{2}+\mathrm{Al}_{7} \mathrm{Cu}_{2} \mathrm{Fe}$. For a further increase in Fe content, the solidification sequence of $0.15 \mathrm{wt}$. $\%$ Fe alloy and $0.20 \mathrm{wt} \%$ Fe alloy remains unchanged. However, the precipitation temperature for $\mathrm{Al}_{6}(\mathrm{FeMn})$ intermetallic phase rises, and its volume fraction also goes up, which leads to the increase of $\mathrm{Al}_{7} \mathrm{Cu}_{2} \mathrm{Fe}$ intermetallic phase (as shown in Figure 2c,d). 


\subsection{Effect of the Fe-Rich Intermetallic Particles on Tensile Fracture Behavior of 2219 Al-Cu Alloys}

Figure 8 indicated that both MDF and heat treatment could improve the tensile fracture behavior. For a metallographic point of view, the fracture mechanisms of 2219 wrought $\mathrm{Al}-\mathrm{Cu}$ alloys are simultaneously dominated by the multi-scale second-phase particles, and grains and grain boundaries [28-30].

Firstly, as mentioned in Figures 2, 4 and 5, coarse grains with an average size of about $380 \pm 40 \mathrm{um}$ (average of at least 100 grains) were observed in $2219 \mathrm{Al}-\mathrm{Cu}-\mathrm{xFe}$ alloys under different processing condition. The large initial grain size was controlled by the solidification condition. However, during MDF at $450{ }^{\circ} \mathrm{C}$, dynamic recovery readily occurred and therefore the deformation energy was timely relieved for grain growth during subsequent solution treatment. Thus, coarse grains were obtained after solution-peak aging treatment, which was agreement with the reference of Dong et al. [1-3,19,20,31]. Therefore, the effect of grains and grain boundaries on tensile fracture behavior of $2219 \mathrm{Al}-\mathrm{Cu}$ alloys as a function of Fe content can be considered to be identical.

Secondly, as mentioned in Figure 7, large amounts of precipitates ( $\theta^{\prime}$ and $\left.\theta^{\prime \prime}\right)$ were observed in $2219 \mathrm{Al}-\mathrm{Cu}-\mathrm{xFe}(\mathrm{x}=0.03,0.20 \mathrm{wt} . \%)$ alloys. In general, volume fraction, size and characteristic of precipitates were of significant roles in influencing the tensile fracture properties. The UTS and YS values of solution-peak aging stage $2219 \mathrm{Al}-\mathrm{Cu}-$ $x F e$ alloys were higher than those of as cast, homogenized and MDF processed 2219 $\mathrm{Al}-\mathrm{Cu}-\mathrm{xFe}$ alloys, while their EL values in solution-peak aging stage were relatively lower than MDF processed alloys due to strengthening precipitates could reduce the ductility of alloys. Compared Figure $7 \mathrm{a}$ with Figure $7 \mathrm{~b}$, the number, size and area fraction of precipitates $\left(\theta^{\prime}\right.$ and $\left.\theta^{\prime \prime}\right)$ did not change obviously with the increase of impurity Fe content. Consequently, the change of Fe content had little influence on values of strength in peak aging heat treatment.

Finally, as mentioned in Figures 2, 4 and 5, the number, size, area fraction, and characteristic of coarse intermetallic particles decreased obviously against different processing approaches (i.e., as-cast, homogenization, $\mathrm{MDF}$, and solution-peak aging treatment). The coarse intermetallics are always considered as hard-brittle phases and therefore those particles have no deformation abilities. Under external service loading, they were easy to dehisce or separate from the matrix and so acted as crack initiators. Therefore, the decrease of primary coarse intermetallics could also improve the tensile fracture properties of alloys.

As mentioned in Figures 2 and 3, the main constituents in as-cast $2219 \mathrm{Al}-\mathrm{Cu}-\mathrm{xFe}$ alloys were $\mathrm{Al}_{2} \mathrm{Cu}$ and $\mathrm{Al}_{7} \mathrm{Cu}_{2}(\mathrm{Fe}, \mathrm{Mn})$ phases. Through different processing approaches, $\mathrm{Al}_{2} \mathrm{Cu}$ particles exhibited an ellipse or spherical shape due to the interactions with fragmentation, dissolution, and diffusion, whereas, $\mathrm{Al}_{7} \mathrm{Cu}_{2}(\mathrm{Fe}, \mathrm{Mn})$ particles were just fragmented into rod-like with sharp edges due to the insolubility of $\mathrm{Fe}$ in $\mathrm{Al}-\mathrm{Cu}$ alloy, as shown in Figures 4-6. To further understand the mechanical characteristics of coarse second-phase particles in the alloys, Pugh $[32,33]$ proposed a method to predict the ductility of the second particles based on their $\mathrm{B} / \mathrm{G}$ and $v$. Here, $\mathrm{B}$ and $\mathrm{G}$ is bulk modulus and shear modulus, respectively, and the values of $B$ and $G$ were calculated using the Voigt-Reuss-Hill approximation from the elastic constant of the second-phase particles. Poisson's ratio $(v)$ can be derived from $B$ and $G$ using formula $v=(3 B-2 G) / 2(3 B+G)$. In the study of Tian et al. [34-36], the $\mathrm{B} / \mathrm{G}$ ratio and $v$ values of $\mathrm{Al}_{2} \mathrm{Cu}$ phase are 2.65 and 0.332 , respectively. However, the $\mathrm{B} / \mathrm{G}$ ratio and $v$ values of $\mathrm{Al}_{7} \mathrm{Cu}_{2}(\mathrm{Fe}, \mathrm{Mn})$ phase are 1.31 and 0.154 , respectively. This means that $\mathrm{Al}_{7} \mathrm{Cu}_{2}(\mathrm{Fe}, \mathrm{Mn})$ particles are easier to act as crack initiators than $\mathrm{Al}_{2} \mathrm{Cu}$ particles. Therefore, the greater the number of $\mathrm{Al}_{7} \mathrm{Cu}_{2}(\mathrm{Fe}, \mathrm{Mn})$ particles was, the lower the plastic nature (as shown in Figure 8). In addition, rod-like $\mathrm{Al}_{7} \mathrm{Cu}_{2}(\mathrm{Fe}$, $\mathrm{Mn}$ ) particles with sharp edges would fracture readily because they were subjected to higher stress concentration, and then cracks propagated along themselves (as shown in Figure $9 c, d$ ). 


\section{Conclusions}

In this paper, the microstructures evolution of Fe-rich intermetallics, mechanical properties of $2219 \mathrm{Al}-\mathrm{Cu}$ alloys with different Fe content against different processing approaches (i.e., as-cast, homogenization, MDF, and solution-peak aging treatment) were studied. The main conclusions are as follows.

(1) When the Fe content was less than $0.03 \mathrm{wt} . \%$, the main constituents were $\mathrm{Al}_{2} \mathrm{Cu}$ intermetallics. As the Fe content increased to $0.10 \mathrm{wt} . \%$, a new needle-like $\mathrm{Al}_{7} \mathrm{Cu}_{2} \mathrm{Fe}$ or $\mathrm{Al}_{7} \mathrm{Cu}_{2}(\mathrm{Fe}, \mathrm{Mn})$ phase presented. Further increase in the Fe content, the characteristic of the needle-like $\mathrm{Al}_{7} \mathrm{Cu}_{2} \mathrm{Fe}$ or $\mathrm{Al}_{7} \mathrm{Cu}_{2}(\mathrm{Fe}, \mathrm{Mn})$ intermetallics did not change, whereas their sizes became longer and wider.

(2) The fragmented $\mathrm{Al}_{7} \mathrm{Cu}_{2} \mathrm{Fe}$ or $\mathrm{Al}_{7} \mathrm{Cu}_{2}(\mathrm{Fe}, \mathrm{Mn})$ intermetallics were obtained during multidirectional forging process. However, they were un-dissolved in the $\alpha$-Al matrix in subsequent solution treatment due to the low tolerance of $\mathrm{Fe}$ in $\mathrm{Al}-\mathrm{Cu}$ alloys. The sharp edges of the fragmented $\mathrm{Al}_{7} \mathrm{Cu}_{2} \mathrm{Fe}$ or $\mathrm{Al}_{7} \mathrm{Cu}_{2}(\mathrm{FeMn})$ particles can act as crack initiators and then as crack propagation paths because they were subjected to higher stress concentrations during deformation.

(3) For all the samples, the same trend of UTS, YS, and EL variation from the processes of as-cast to peak aging stage. The as-cast samples presented relatively low values of UTS/YS/EL, i.e., 165.35/92.56 MPa and 7.34\%, 157.61/80.67 MPa and 6.79\%, $140.29 / 74.44 \mathrm{MPa}$ and $5.41 \%$, and $133.77 / 66.52 \mathrm{MPa}$ and $4.98 \%$ as a function of the $\mathrm{Fe}$ content ranging from 0.03 to $0.20 \mathrm{wt} . \%$. The MDF samples possessed the maximum EL values, i.e., $15.99 \%, 13.56 \%, 11.46 \%$, and $7.09 \%$ corresponding to the Fe contents of 0.03 , $0.10,0.15$, and $0.20 \mathrm{wt} . \%$, respectively. The solution-peak aging treatment significantly increased the UTS/YS values by at least $270 / 90 \mathrm{MPa}$, respectively, compared with the as-cast condition.

(4) For peak aging condition, the UTS, YS, and EL values decreased with the increase of Fe content. For 0.03 wt.\% Fe alloy, the UTS, YS, and EL values were $445.64 \mathrm{MPa}$, $333.76 \mathrm{MPa}$, and $15.14 \%$, respectively. Increasing the Fe content from 0.03 to $0.20 \mathrm{wt} . \%$, the UTS, YS, and EL decreased by $36 \mathrm{MPa}, 25 \mathrm{MPa}$, and $57.92 \%$, respectively.

Author Contributions: D.X.: Conceptualization, Methodology, Investigation, Writing original manuscript. C.Z.: Draft revision, Supervision, writing assistance. C.X.: Writing assistance. K.C.: Deriving the theoretical framework, Supervision, Design guide. All authors have read and agreed to the published version of the manuscript.

Funding: This work was funded by the National Natural Science Foundation of China (Grant No. U1637601), the Transformation of Scientific and Technological Achievements Program of Jiangsu Province (BA2015075), the National Key Research and Development Program of China (Grant No. 2016YFB0300801), the Major Research Equipment Development Projects of National Natural Science Foundation of China (Grant No. 51327902), the Science and Technology Major Project of Guangxi, China (Grant No. AA17204012), and the Opening Project of Guangxi Colleges and Universities Key Laboratory of robot and welding (Grant No. JQR2018ZR02).

Conflicts of Interest: The authors declare no conflict of interest.

\section{References}

1. He, H.; Yi, Y.-P.; Huang, S.-Q.; Zhang, Y. Effects of deformation temperature on second-phase particles and mechanical properties of 2219 Al-Cu alloy. Mater. Sci. Eng. A 2018, 712, 414-423. [CrossRef]

2. Xu, D.F.; Chen, K.H.; Chen, Y.Q.; Chen, S.Y. Evolution of the second-phase particles and their effect on tensile fracture behavior of 2219 Al-xCu alloys. Metals 2020, 10, 197. [CrossRef]

3. Dong, F.; Yi, Y.; Huang, C.; Huang, S. Influence of cryogenic deformation on second-phase particles, grain structure, and mechanical properties of Al-Cu-Mn alloy. J. Alloys Compd. 2020, 827, 154300. [CrossRef]

4. Backerud, L.; Chai, G.; Tamminen, J. Solidification Characteristics of Aluminum Alloys; American Foundrymen's Society: Schaumburg, IL, USA, 1990; p. 266.

5. Zhang, W.; Lin, B.; Zhang, D.; Li, Y. Microstructures and mechanical properties of squeeze cast Al-5.0Cu-0.6Mn alloys with different Fe content. Mater. Des. 2013, 52, 225-233. [CrossRef] 
6. Liu, K.; Cao, X.; Chen, X.-G. Solidification of Iron-Rich Intermetallic Phases in Al-4.5Cu-0.3Fe Cast Alloy. Met. Mater. Trans. A 2010, 42, 2004-2016. [CrossRef]

7. Tseng, C.-J.; Lee, S.-L.; Wu, T.-F.; Lin, J.-C. Effects of Fe Content on Microstructure and Mechanical Properties of A206 Alloy. Mater. Trans. JIM 2000, 41, 708-713. [CrossRef]

8. Lin, B.; Xu, R.; Li, H.; Xiao, H.; Zhang, W.; Li, S. Development of high Fe content squeeze cast 2A16 wrought Al alloys with enhanced mechanical properties at room and elevated temperatures. Mater. Charact. 2018, 142, 389-397. [CrossRef]

9. Tseng, C.-J.; Lee, S.-L.; Tsai, S.-C.; Cheng, C.-J. Effects of manganese on microstructure and mechanical properties of A206 alloys containing iron. J. Mater. Res. 2002, 17, 2243-2250. [CrossRef]

10. Liu, K.; Cao, X.; Chen, X.-G. Effect of Mn, Si, and Cooling Rate on the Formation of Iron-Rich Intermetallics in $206 \mathrm{Al}-\mathrm{Cu}$ Cast Alloys. Met. Mater. Trans. A 2012, 43, 1231-1240. [CrossRef]

11. Xu, R.; Lin, B.; Li, H.Y.; Xiao, H.Q.; Zhao, Y.L.; Zhang, W.W. Microstructure evolution and mechanical properties of Al-6.5Cu0.6Mn-0.5Fe alloys with different Si additions. Trans. Nonferrous Met. Soc. China 2019, 29, 1583-1591. [CrossRef]

12. Zhang, W.; Lin, B.; Fan, J.; Zhang, D.; Li, Y. Microstructures and mechanical properties of heat-treated Al-5.0Cu-0.5Fe squeeze cast alloys with different Mn/Fe ratio. Mater. Sci. Eng. A 2013, 588, 366-375. [CrossRef]

13. Liu, Y.; Luo, L.; Han, C.; Ou, L.; Wang, J.; Liu, C. Effect of Fe, Si and Cooling Rate on the Formation of Fe- and Mn-rich Intermetallics in Al-5Mg-0.8Mn Alloy. J. Mater. Sci. Technol. 2016, 32, 305-312. [CrossRef]

14. Lin, Y.; Wu, B.; Li, S.; Mao, S.; Liu, X.; Zhang, Y.; Wang, L. The quantitative relationship between microstructure and mechanical property of a melt spun Al-Mg alloy. Mater. Sci. Eng. A 2015, 621, 212-217. [CrossRef]

15. Lichioiu, I.; Peter, I.; Varga, B.; Rosso, M. Preparation and Structural Characterization of Rapidly Solidified Al-Cu Alloys. J. Mater. Sci. Technol. 2014, 30, 394-400. [CrossRef]

16. Chobaut, N.; Carron, D.; Drezet, J.-M. Characterisation of precipitation upon cooling of an AA2618 Al-Cu-Mg alloy. J. Alloys Compd. 2016, 654, 56-62. [CrossRef]

17. Lin, B.; Zhang, W.; Zhao, Y.; Li, Y. Solid-state transformation of Fe-rich intermetallic phases in Al-5.0Cu-0.6Mn squeeze cast alloy with variable Fe contents during solution heat treatment. Mater. Charact. 2015, 104, 124-131. [CrossRef]

18. Lin, B.; Zhang, W.W. Effect of heat treatment on morphology of Fe-rich intermetallics in Al-Cu alloys. Mater. Sci. Technol. 2016, 33, 738-743. [CrossRef]

19. Zhang, Y.; Li, R.; Chen, P.; Li, X.; Liu, Z. Microstructural evolution of $\mathrm{Al}_{2} \mathrm{Cu}$ phase and mechanical properties of the large-scale $\mathrm{Al}$ alloy components under different consecutive manufacturing processes. J. Alloys Compd. 2019, 808, 151634. [CrossRef]

20. Zhang, L.; Li, X.; Li, R.; Jiang, R.; Zhang, L. Effects of high-intensity ultrasound on the microstructures and mechanical properties of ultra-large $2219 \mathrm{Al}$ alloy ingot. Mater. Sci. Eng. A 2019, 763, 138-154. [CrossRef]

21. Liu, Z.; Li, R.; Jiang, R.; Zhang, L.; Li, X. Scalable Ultrasound-Assisted Casting of Ultra-large 2219 Al Alloy Ingots. Met. Mater. Trans. A 2019, 50, 1146-1152. [CrossRef]

22. Peng, H.; Li, R.; Li, X.; Ding, S.; Chang, M.; Liao, L.; Zhang, Y.; Chen, P. Effect of Multi-Source Ultrasonic on Segregation of Cu Elements in Large Al-Cu Alloy Cast Ingot. Materials 2019, 12, 2828. [CrossRef] [PubMed]

23. He, H.; Yi, Y.-P.; Huang, S.-Q.; Zhang, Y. Effects of cold predeformation on dissolution of second-phase Al2Cu particles during solution treatment of 2219 Al-Cu alloy forgings. Mater. Charact. 2018, 135, 18-24. [CrossRef]

24. Lu, Y.; Wang, J.; Li, X.; Li, W.; Li, R.; Zhou, D. Effects of pre-deformation on the microstructures and corrosion behavior of 2219 aluminum alloys. Mater. Sci. Eng. A 2018, 723, 204-211. [CrossRef]

25. Belov, N.A.; Eskin, D.G.; Aksenov, A.A. Multicomponent Phase Diagrams, Applications for Commercial Aluminum Alloys; Elsevier: London, UK, 2005.

26. Tang, K.; Du, Q.; Li, Y. Modelling microstructure evolution during casting, homogenization and ageing heat treatment of Al-Mg-Si-Cu-Fe-Mn alloys. Calphad 2018, 63, 164-184. [CrossRef]

27. Li, Y.; Arnberg, L. A eutectoid phase transformation for the primary intermetallic particle from $\mathrm{Alm}(\mathrm{Fe}, \mathrm{Mn})$ to $\mathrm{Al} 3(\mathrm{Fe}, \mathrm{Mn})$ in AA5182 alloy. Acta Mater. 2004, 52, 2945-2952. [CrossRef]

28. Sharma, V.; Kumar, K.S.; Rao, B.N.; Pathak, S. Effect of microstructure and strength on the fracture behavior of AA2219 alloy. Mater. Sci. Eng. A 2009, 502, 45-53. [CrossRef]

29. Elgallad, E.M.; Zhang, Z.; Chen, X.-G. Effect of two-step aging on the mechanical properties of AA2219 DC cast alloy. Mater. Sci. Eng. A 2015, 625, 213-220. [CrossRef]

30. An, L.; Cai, Y.; Liu, W.; Yuan, S.; Zhu, S.; Meng, F. Effect of pre-deformation on microstructure and mechanical properties of 2219 aluminum alloy sheet by thermomechanical treatment. Trans. Nonferrous Met. Soc. China 2012, 22, 370-375. [CrossRef]

31. Liu, L.; Wu, Y.; Gong, H.; Dong, F.; Ahmad, A. Modified kinetic model for describing continuous dynamic recrystallization behavior of Al 2219 alloy during hot deformation process. J. Alloys Compd. 2020, 817, 153301. [CrossRef]

32. Pugh, S. Relations between the elastic moduli and the plastic properties of polycrystalline pure metals. Philos. Mag. 1954, 45, 823-843. [CrossRef]

33. Li, C.M.; Zeng, S.M.; Chen, Z.Q.; Cheng, N.P.; Chen, T.X. First-principles calculations of elastic and thermodynamic properties of the four main intermetallic phases in Al-Zn-Mg-Cu alloys. Comput. Mater. Sci. 2014, 93, 210-220. [CrossRef]

34. Tian, J.; Yu-Hong, Z.; Hou, H.; Han, P. First-principles investigation of the structural, mechanical and thermodynamic properties of $\mathrm{Al} 2 \mathrm{Cu}$ phase under various pressure and temperature conditions. Solid State Commun. 2017, 268, 44-50. [CrossRef] 
35. Xie, D.; Guo, H.; Yang, X.; Ma, T. First-principles study of structural, mechanical, and electronic properties of typical ironcontaining phases in Al-Cu alloys under different pressures. Phys. B Condens. Matter 2019, 555, 112-117. [CrossRef]

36. Tian, J.; Yu-Hong, Z.; Wen, Z.; Hou, H.; Han, P. Physical properties and Debye temperature of Al $7 \mathrm{Cu} 2 \mathrm{Fe}$ alloy under various pressures analyzed by first-principles. Solid State Commun. 2017, 257, 6-10. [CrossRef] 